\title{
جريمة الهروب العسكري في القانون
}

\section{The crime of fleeing}

\author{
in law
}

\author{
اسراء فاضل كاظم \\ أ.المتمرس.د. فخري عبد الرزاق الحديثي \\ طالبة ماجستير \\ كلية القانون \\ كلية القانون/ جامعة بغداد \\ جامعة بغداد
}


يتميـز البحــث فـي الجـر ائم العــكرية بالأهميــة والخطــورة فـتكمن أهميتهــا فـي مــا

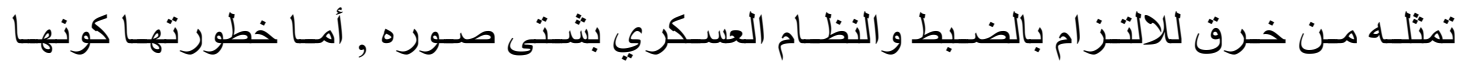
تمـس مصــالح القـوات المسـلحة ورتشـكل الجريمـة العسـكرية ثغـرة لا تكـون أثنار هـا واضـحة

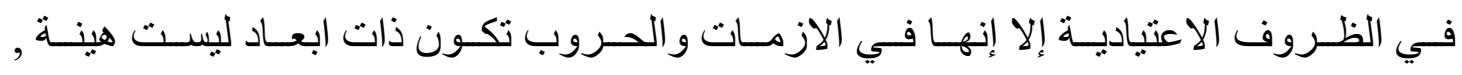

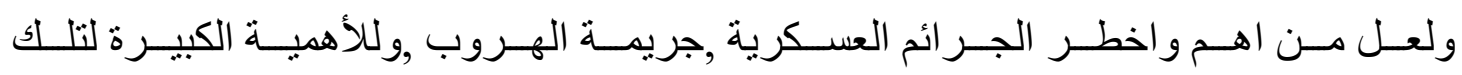
الجريمـة سـنتناولها بالبحـث في مبحثثين سنخصـص المبحـث الاول لمفهوم جريمـة الهـروب أما المبحث الثاني سنتناول فيه موضع الهروب في القانون

\begin{abstract}
Researches military crimes is important and dangerous and it is important in it is violation of the obligation and all forms military order in all, it is dangerous because it affects the interests of the armed forces, military crime is a loophole whose effects are not tangible in normal circumstances however, in the crises and wars ,they have serious dimensions, one of the most dangerous and crimes is the crime of fleeing and because the great importance of this crime will be dealt with in two section will be devoted the first of the concept of the crime of fleeing and the second will address the legal concept of this crime.
\end{abstract}




\section{مقدمة البحث}

\section{Introduction}

الحمد لله رب العالمين و افضل الصلاة و اتم التسليم على سيد المرسلين نبينا محمد وعلى اله الطيبين الطاهرين وصحبه الكر ام اجمعين .....وبعد

إن جريمة الهروب العسكرية من الجرائم الخطرة الماسة بمصلحة القوات المسلحة وأمن

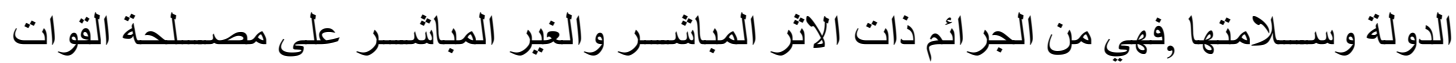

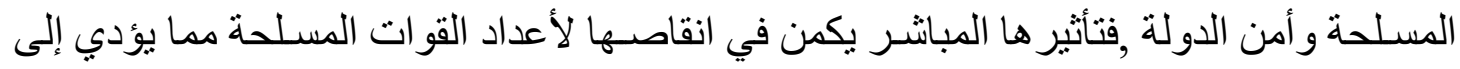

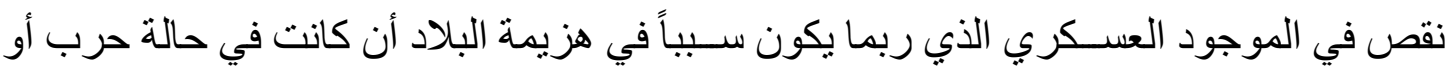

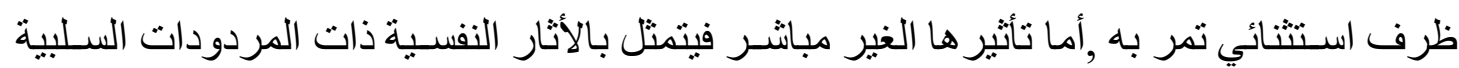

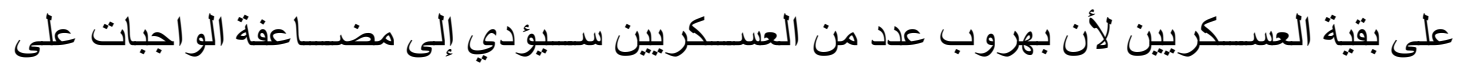

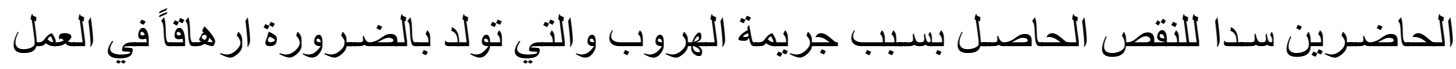
وتذمر اً في الواجب ,مما يؤدي إلى عدم تحقيق القطعة العسكرية للواجبات المنوطة بها, وبالر غم

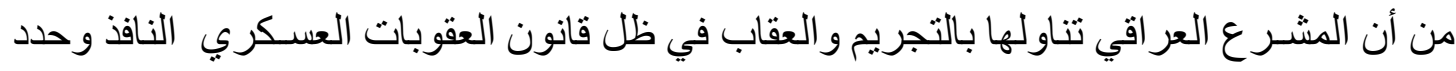

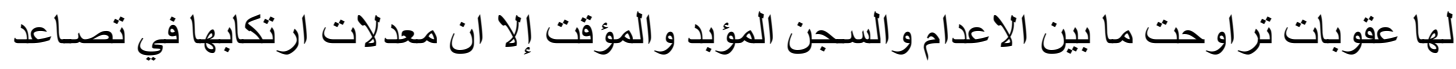
مستمر فالإحصائبات تشبر إلى بلو غها عشرات الالاف سنويار رغم أن الخدمة العسكرية طوعية

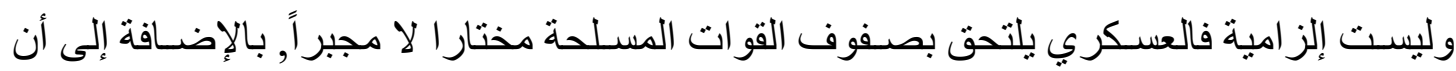
الكتابات عنها لا تز ال قليله و نادرة , فز يادة معدلات الجريمة وقلة الكتابات عنها رغم اهميتها

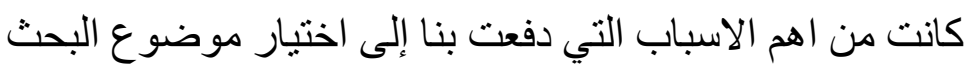

\section{اولاً: اهمية الموضوع وسبب اختياره(Important of subject)}

يتضح من خلال البحث في جريمة الهروب العسكرية بأنها من المو اضيع المهمة والخطرة الماسة

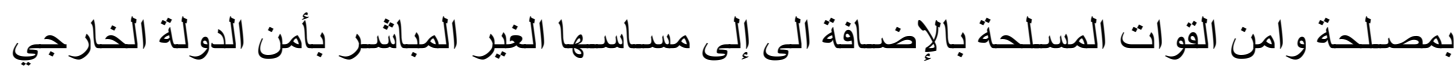

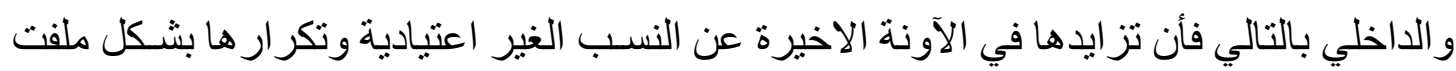

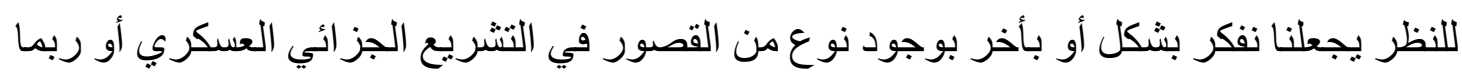
خلل في التطبيق القضـائي بالتالي يتطلب من و اضـعي التشـريع البحث عن أصل المشكلة و ايجاد

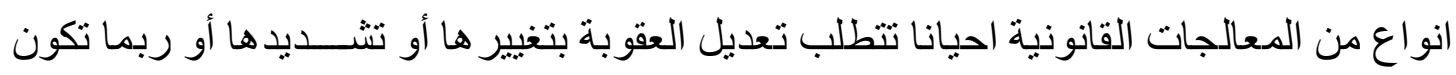


العقوبة ملائمة ومتو افقة مع الجريمة المرتكبة إلا ان الخلل و القصــور يكون بالإجر اءات ســواء

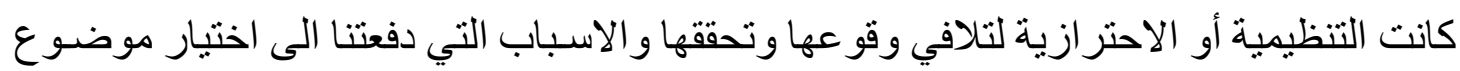

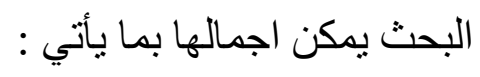

1-زيادتها في السنوات الأخيرة بشكل كبير لأسباب كثيرة ومتعددة منها الفسـاد المالي و الاداري

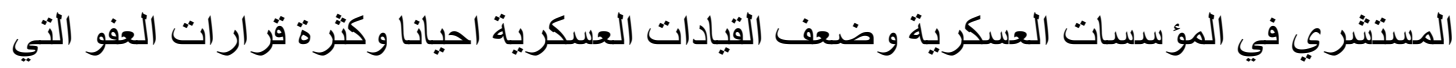
تصـدرها القيادة العليا للقو ات المسـلحة و افتقار العسكريين الى التدريب و التأهيل الكافي واحيانا ضعف الروح القتالية لدى العسكريين بالإضافة الى التثبط الاعلامي المضاد بالتالي تلك الاسباب

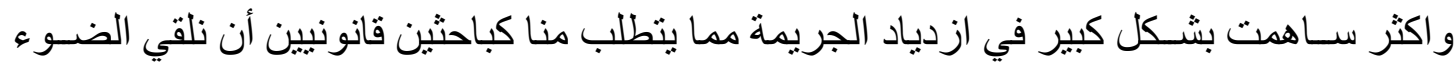
على اهم الثغر ات القانونية لتلافي زيادتها مستقبلا. ك-بالر غم من الاهمية الكبيرة لتلك الجريمة بتأثير ها الكبير على القوات المســلحة وقدر اتها من خلال تسببها بضرر مباشر للقو ات المسلحة عند هروب احد العسكريين الا ان الكتابات عنها قليلة ونادرة مما يشكل ثغرة لابد من تلافيها بزيادة البحوث القانونية العسكرية و هذه احد الاسباب التي لئي دفعتني الى البحث في هذا الموضوع لكي يساهم ولو بشكل يسير في سد تللك الثغرة.

ثانيا :منهجية البحث (Research methodology) طبيعة البحث في جريمة الهروب العسـكرية بدراســة احكامها الموضــــ عية املت علينا اتباع المنهج القانوني الوصفي المقارن

ثُاثثاً: تقسيم البحث (Division of research)

سنقوم بتقسيم البحث إلى مبحثين نتناول في المبحث الاول منه مفهوم جريمة الهروب بتقسيمه إلى

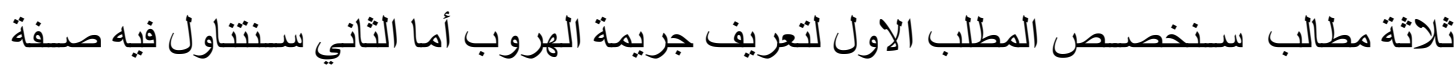

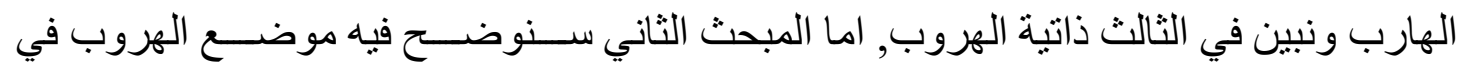

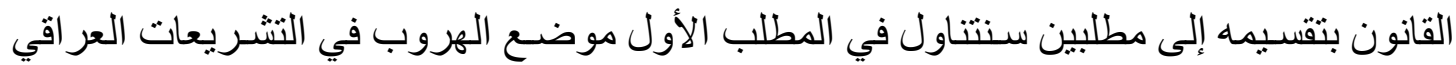
أما المطلب الثاني سنتناول فيه موضع الهروب في التثريعات المقارنة 


\section{Introducition}

The crime of fleeing from the military service is one of the dangerous crimes that related to the interest of armed forces and security and safety of the state .It is one of the crimes that has direct and indirect effect upon interest of armed forces and stat security. Its direct effect being in reducing the number of armed forces which leads to the decreasing the required number to defend the state which may causes defeating for the country in case of war or extraordinary circumstances that passes through the country.

Its indirect effects being in psychological effects with negative reactions upon the rest of other military soldiers because by fleeing a numbers of the soldiers will lead to multiply the duties and responsibilities upon the existing soldiers in order to replenish that occurred due to fleeing crime, that necessarily will generates exhaustion and grumbling in achieving the duties and tasks and eventually the main duty will not be achieved accurately

Although the Iraqi legislator dealt with the crime and the penalty within valid military law and put penalties for crimes related with fleeing ranged from execution and life imprisonment and temporary, but still the rate of its commitment is high continuously.

Statistics refer that it reaches thousands of military persons flee annually although military service is voluntary not compulsory , in addition to that printed literature about this subject is very rare . Increasing in crime rate, rare writing upon this important issue though it is important stimulate us to write on the subject in our research 


\section{(The first topic) المبحث ألأول}

\section{مفهوم جريمة الهروب (The concept of fleeing)}

مرت تللك الجريمة بمر احل عديدة تطورت خلالها إلى أن اصبحت بالثكل المعروفة عليه الان ففي العصـــور القديمة نجد ان بعض القو انين القديمة قد عرفت جريمة الهروب العســكرية و ادرجتها ضمن قانون خاص بالعقوبات العسكرية وتفاوتت عقوباتها في الثدة تبعا لمدى الاعتداد

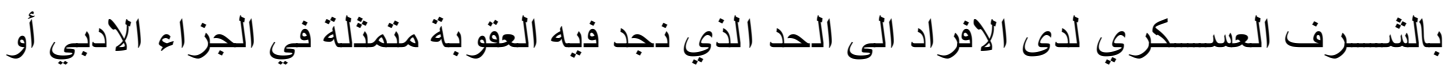

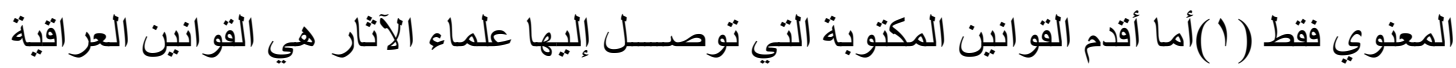

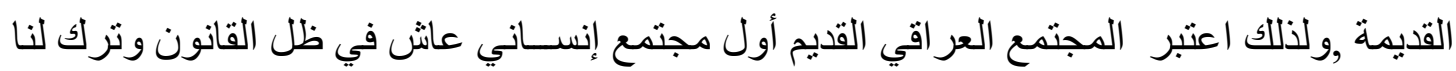
بعض معالم ذلك القانون(Y),ســـواء في الجانب المدني أو العسـكري ـ فأولى الجر ائم التي ظهرت

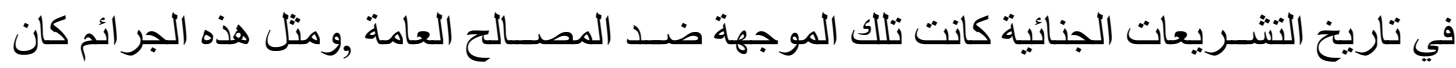
يعاقب عليها بعقوبات شديدة بينما كانت الجر ائم المرتكبة ضد الأفر اد تعد من القضايا الخاصة بين

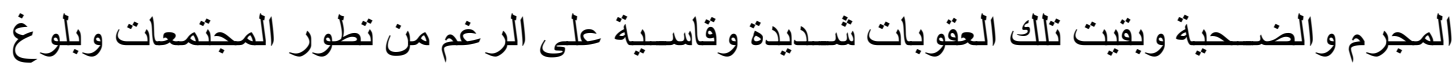
درجة حضسارنها درجة من الرقي (r) فالمجتمعات العر اقية في العصسور القديمة عرفت جريمة الهروب و عدتها من الجر ائم المضرة بمصلحة الجماعة و عاقبت عليها بقسوة شديدة و على سبيل المثال في العصر الاشوري نلاحظ حرص الملوك الاشوريون على إعطاء مسألة الهروب أولوية كبيرة على الرغم من تجنبهم ذكر ها ضـــن النصــوص الملكية ولعل الغرض من ذلك المحافظة على الروح المعنوية العالية للجنود بعدم ذكر ها ـ وللحد من تللك الجريمة اتخذو ا عدة اسـاليب عدة أســاليب كجز اء للهروب لعل من أهم الأســاليب كان أســلوب العقاب عند أخلال الفرد بو اجبه

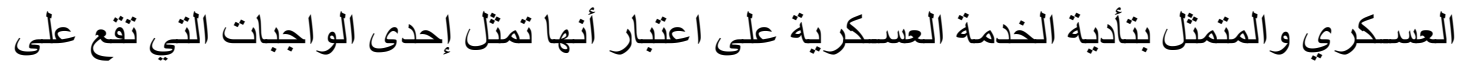

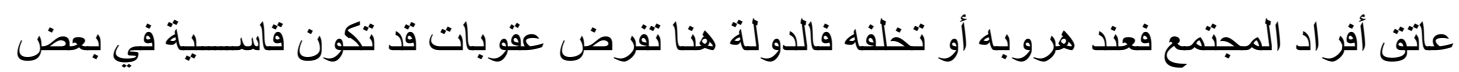

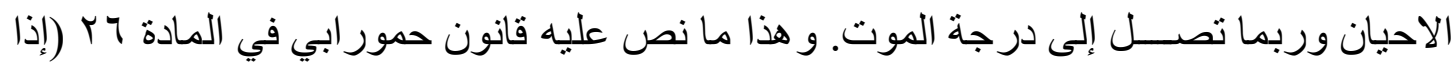

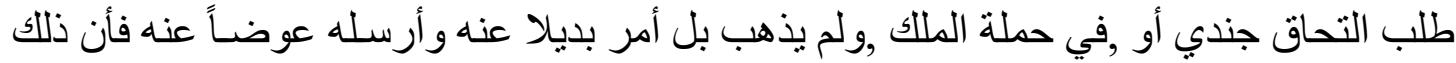
الجندي يعدم إلى جانب قيامها بو سائل أخرى ليكون ذلك الفرد عبرة لمن تسول له نفسه بالتخاذل

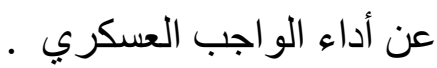

أما بالنسبة للمصـريين القدماء فقد عرفوا كذلك جريمة الهروب العسكرية حيث كانو ا يعتبرونها من اخطر الجر ائم العسكرية وكانت تستوجب عقوبة الاعدام وولكن المتهم بها احيانا كان يعفى من عقابها إذا ما قام بعمل بطولي بعد ذللك يعوض به جريمته في الهروب (ع) . 
كـذلك القـانون الرومـاني فقـــــــرف جريمــة الهـروب العسـكرية و اســـاهـا الجـر ائم البحتــة و ادرجهـا في قـانون خـاص بالعقوبـات العسكرية رأمـا العقوبـات التـي وضـعها لتلك الجريمـة

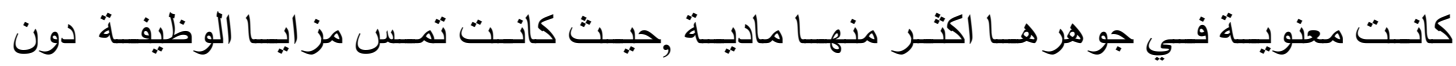
شخص الجاني كالتزيل من الرنبة و النقل من مكان ارفع الى مكان ادنى (0). أمــا فـي العصـور الوسـطى عرفـت المجتمعـات البثـرية ايضــا جريمـة الهـروب العسـكرية وقامـت ايضـا بوضــع قـانون خـاص بالعقوبـات العسـكرية ركالقـانون الـذي اصـــره لودفيكـو الثـاني ملـك ايطاليـا عـام (77 7 7) المتضــمن نصـوص جنائيــة لمعاقبـة مـن يخـالف نصـوص التعبئة و التجنيد بالإضافة إلى إنه تضمن نصوص خاصة بالتنظيم العسكري (†) وفي الثـريعة الاسـلامية عرفـت الجريمــة العسـكرية البحتـة او الصـرفة بمناسـبة الفتوحـات

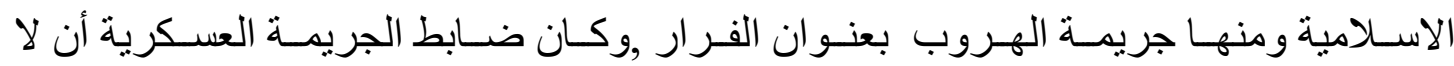
تخـالف نصــاصــريحا ورد فـي القـران الكـريم أو الســنة أو الاجمــاع. .(V) وعـرف الفقـهـ

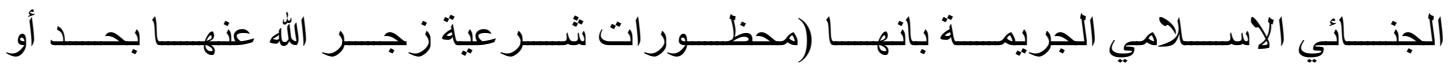

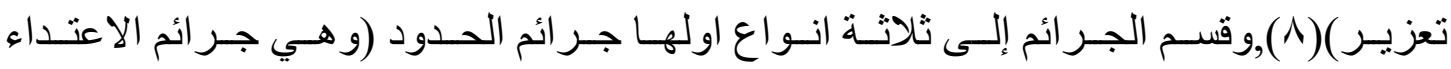
علـى حقـوق الله المحضــة (الحقـوق العامـة كجريمـة الـردة )أو (الحقـوق المشـتركة بـين الله

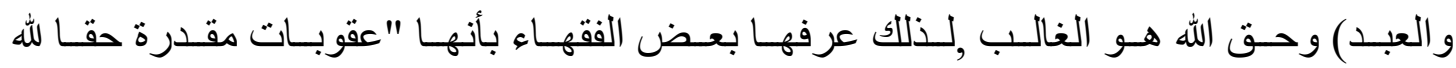

و النـوع الثـاني جـر ائم القصــاص وهـي ايضــا جـر ائم محـددة وعقوباتهـا مقـدرة ثبــت اصـلها بالقران الكريم وثبت تفصيلها بالسنة النبوية الثريفة وتشمل جر ائم الاعتداء على النفس. امـا النـوع الثالـث مـن الجـر ائم هـي جـر ائم التعـــير وهـي الجـر ائم التـي يعاقب عليهـا بعقوبـة او اكثتر مـن عقوبـات التعزيـر ومعنـى التعزيـر :الـتأديب ووقــــــرت الثـريعة الاسـلامية على عدم تحديـد عقوبـة كل جريمـة تعزيريـة و اكتقـت بمجمو عـة مـن العقوبـات لهذه الجـر ائم تبـدأ بـأخف العقوبـات و تنتهـي بأثـــــا وتركت للقاضــي أن يختـار العقوبـة فـي كـل جريمـة

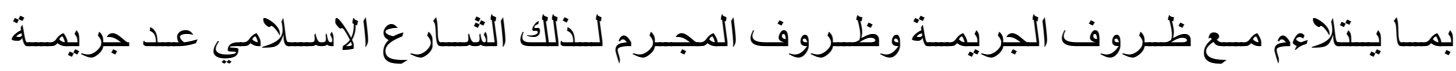

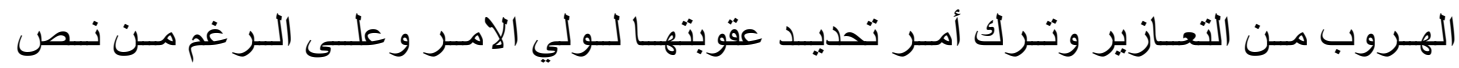

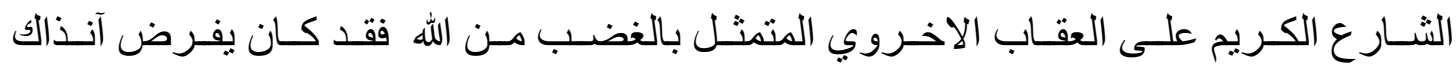
عقـاب دنيـوي علــى المتخلفـين والفـارين وهـو التشــير بهـم بــين النـاس ,ومقـاطعتهم مسن

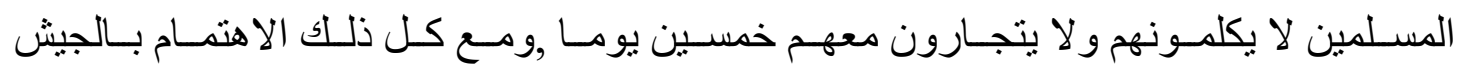


و الجـر ائم العسـكرية و اهميتهـا إلا أن الثـريعة الاسـلامية لـم تخـص الحيـاة العسـكرية بأحكـام

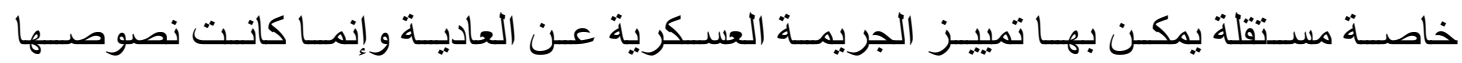
(1. (1) موجهة للجميع. ()

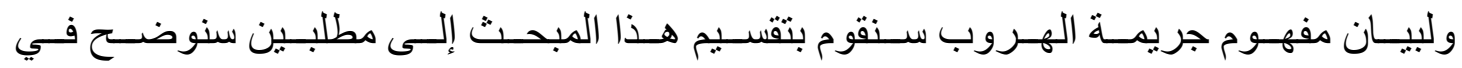
المطلـب ألأول تعريـف الهـروب فـي فـرعين سنخصـص الفـرع الاول لتعريـف الهـرب لغـة أمـا الفـرع الثـاني سـنبين فيـهـ المعنـى الاصــلاحي للهـروب , أمـا المطلـب الثـاني سـنتناول فيـه صـفة الهـارب وسنخصـص المطلـب الثالــ لطبيعـة جريمـة الهـروب بييـان خصـائص الجريمة في الفرع الأول , أما الفرع الثاني سنوضح فيه ذاتية جريمة الهروب .

\section{المطلب ألأول (First requirement)}

\section{تعريف الهروب(Definition the flee)}

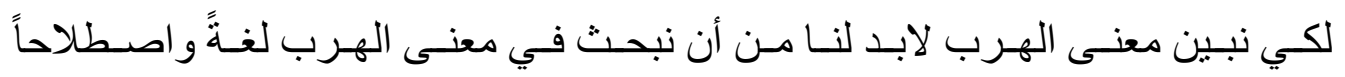

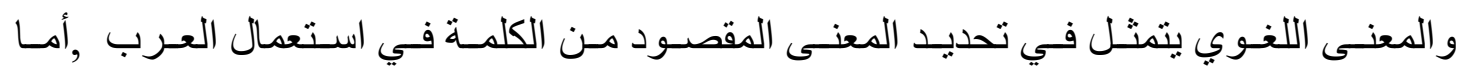

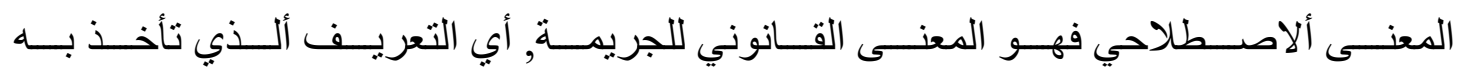

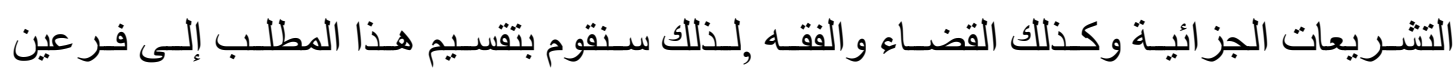

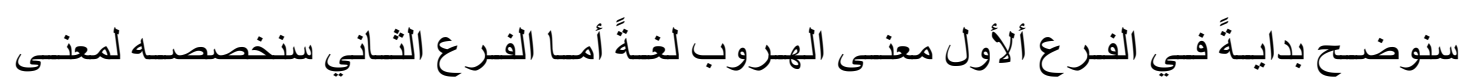
الهروب اصطلاحاً

\section{(Section I) (الفرع ألأول)}

\section{(definition the flee in language) الهرب لغةً}

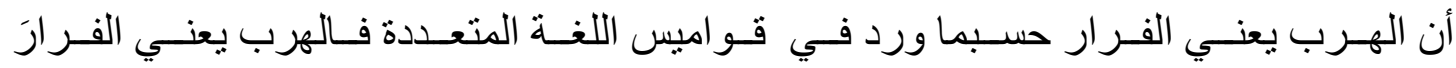

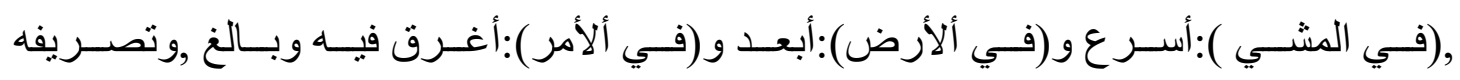

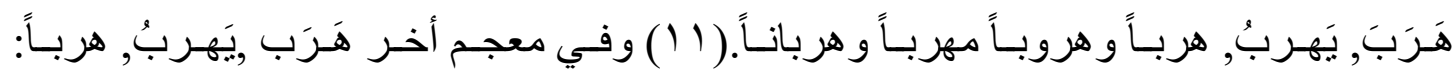

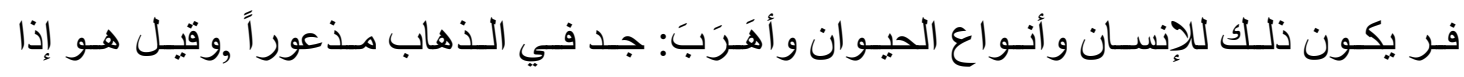

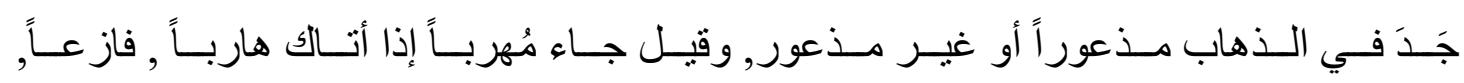




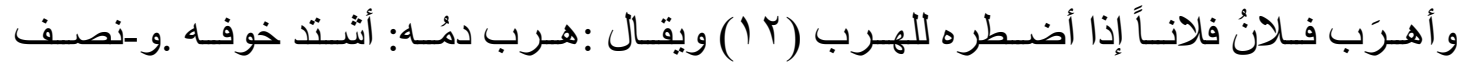

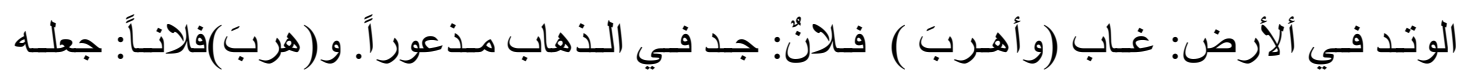

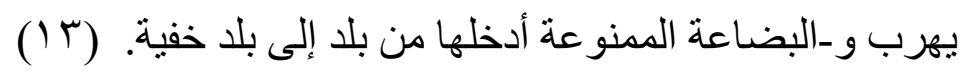

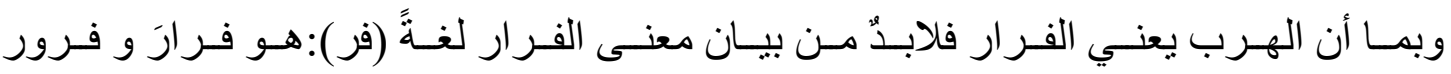
وفروة وأفررنه حملته على أن يفر ( ( ).

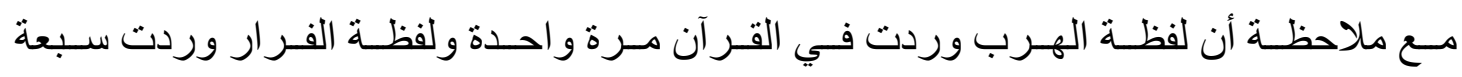

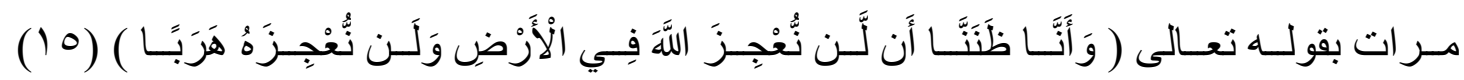

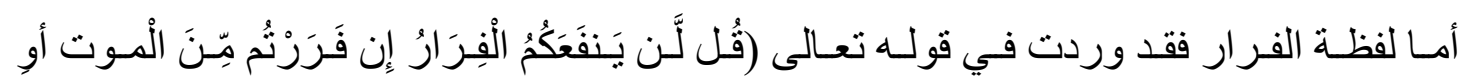

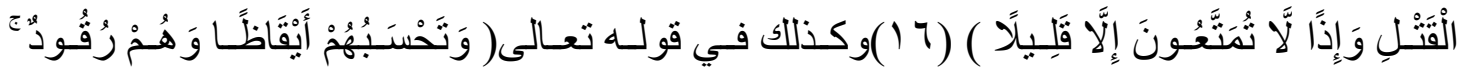

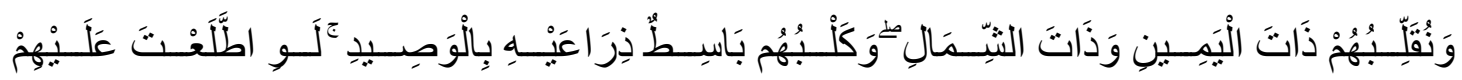

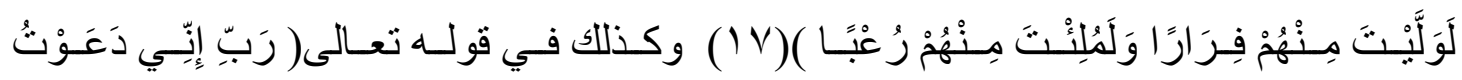

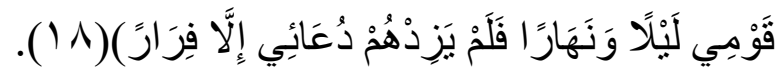

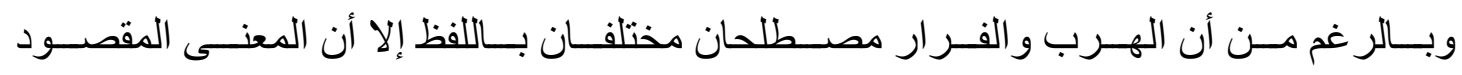

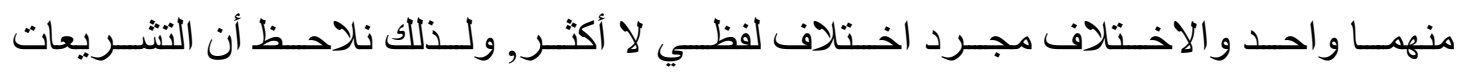

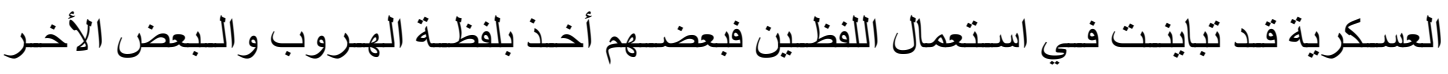

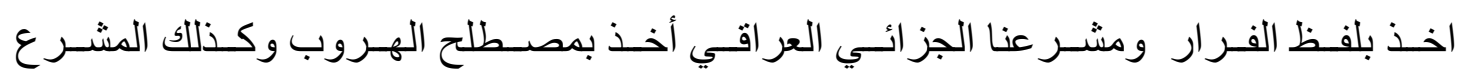

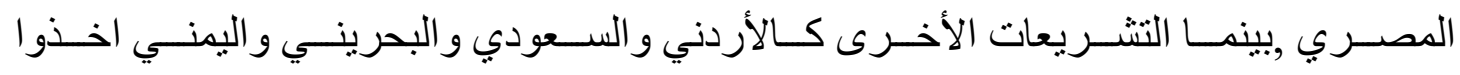

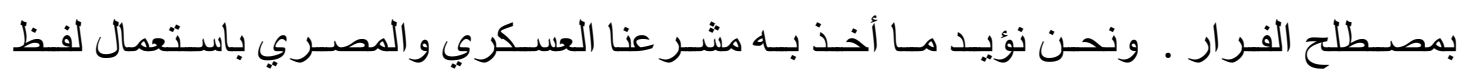
الهروب كون إنها أوضح معنى و أكثر استعمالاً في الفقه والقضاء. وناء. 


\section{(section II ) (الفرع الثاني )}

\section{(The conventional meaning of flee (المعى الاصطلاحي للهرب )}

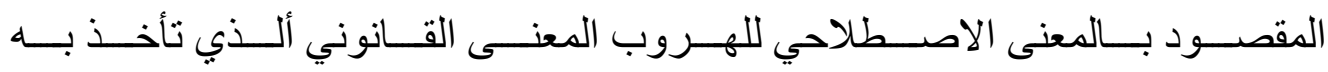

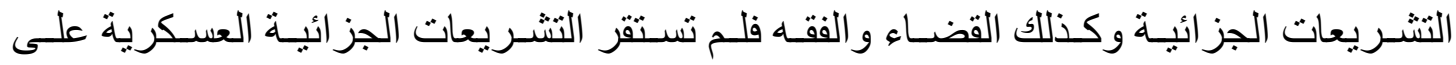

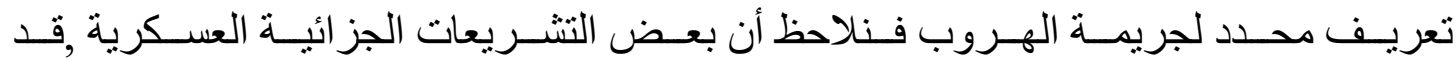

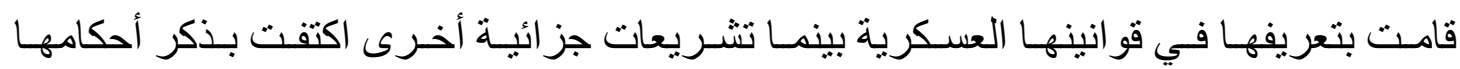

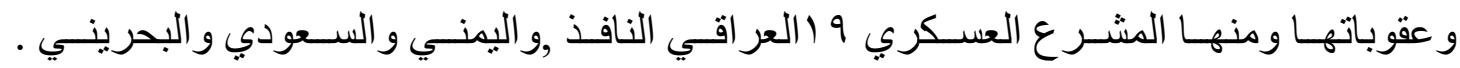

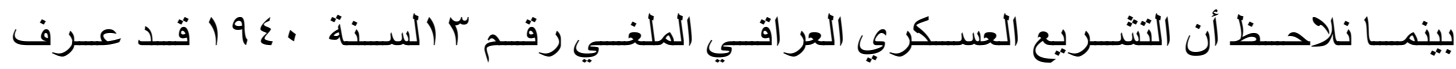

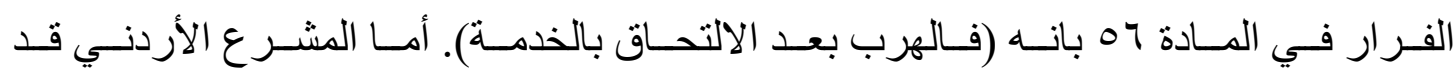

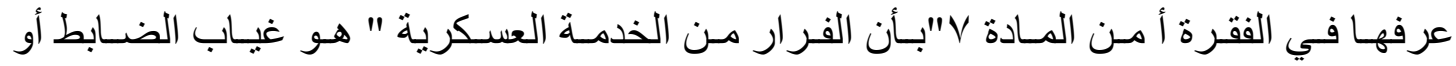

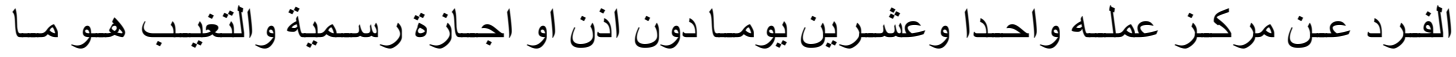

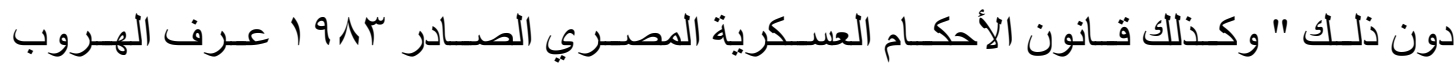

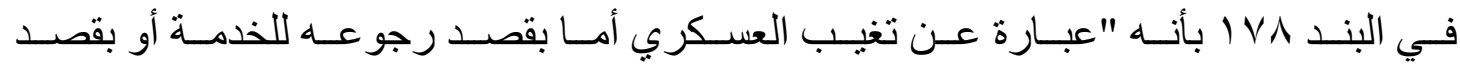

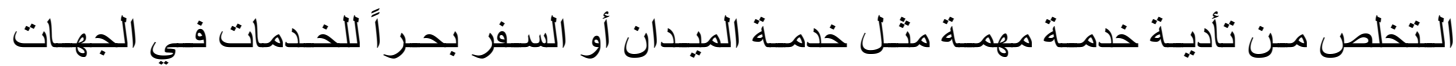

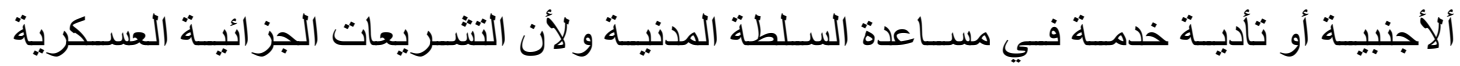

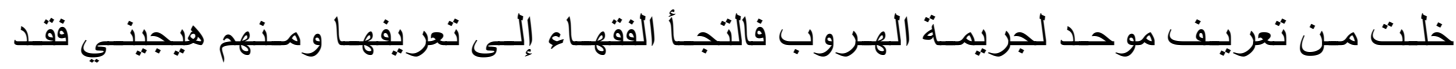

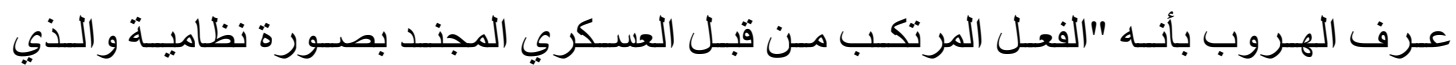

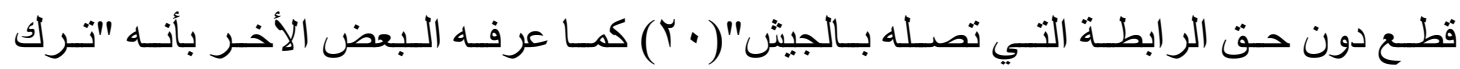

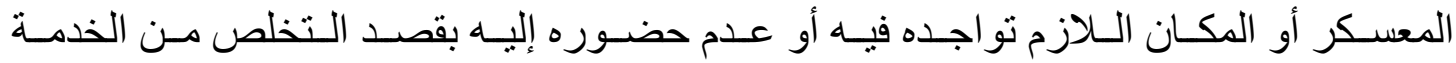

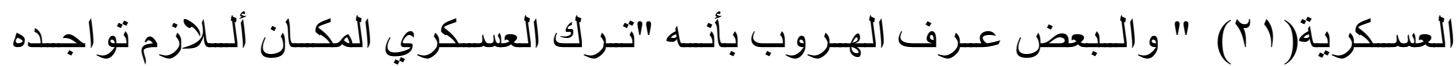

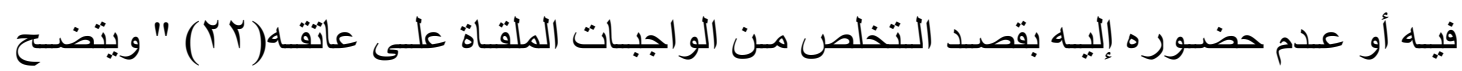

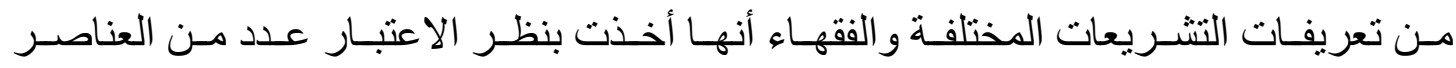

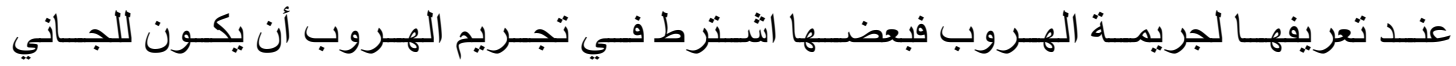

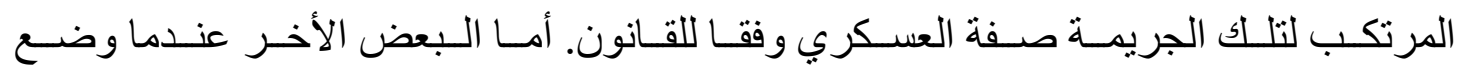
الــص العقـابي وعرفهـا نظـر إلـى المصـلحة التـي سـوف تتــرض للخطـر مـن جـر اء تلـك

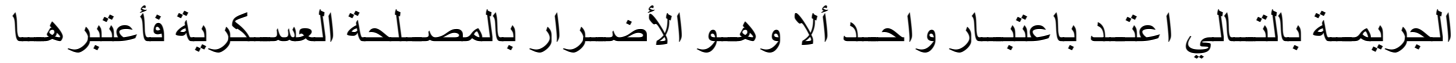

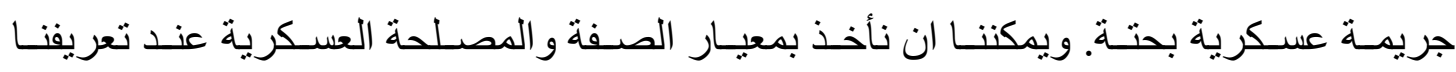




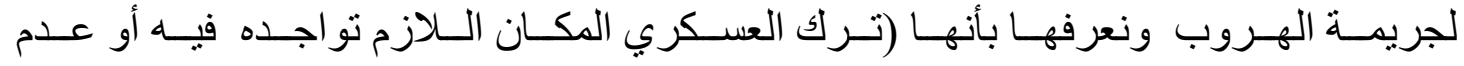
حضوره إليه ويترتب علي هروبه اضر اراً بالمصلحة العسكرية ) .

المطلب الثاني (The second requirement)

\section{صفة الهارب( characteristics of the person who is flee )}

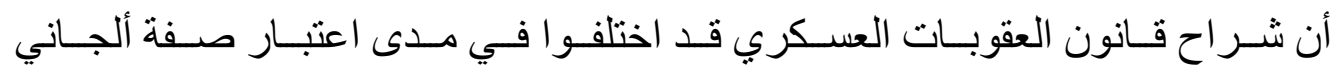

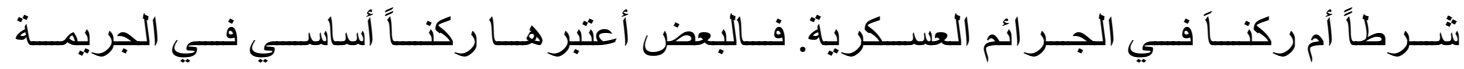

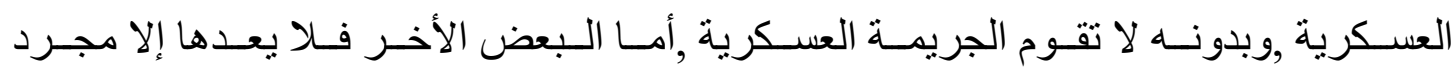

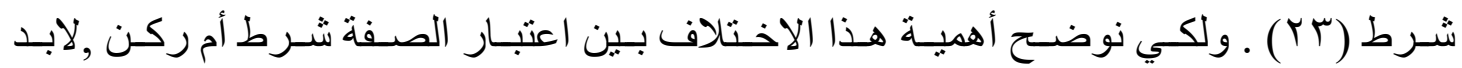

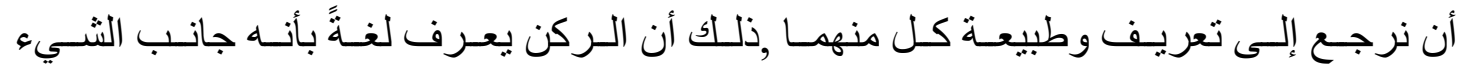

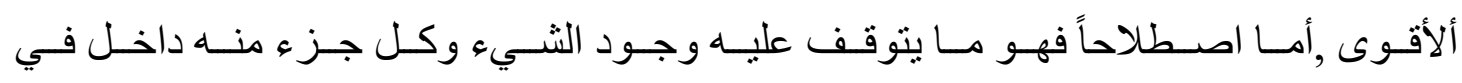

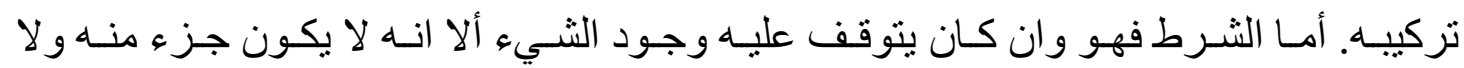

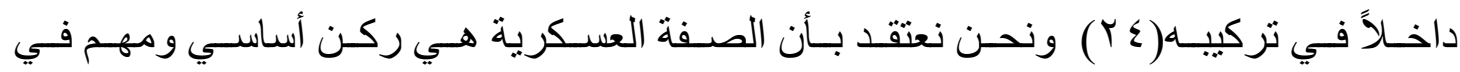

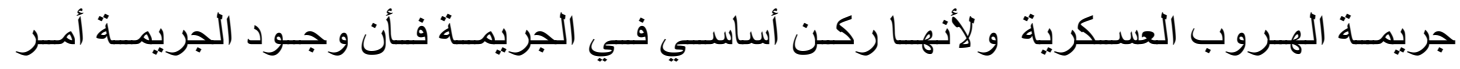

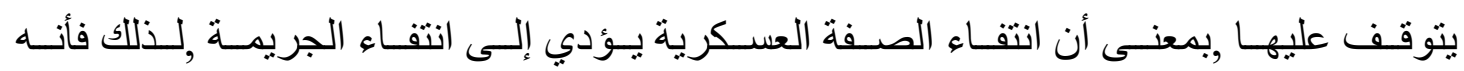
يشـترط في أي جريمـة عسـكرية مرتكبـة وفـق أحكـام قـانون العقوبـات العسـكري أن يكـون مرتكبهـا مـن الأشـخاص الذين يسـري عليهم قـانون العقوبـات العسكري ومـن ثم يلزم تـوافر

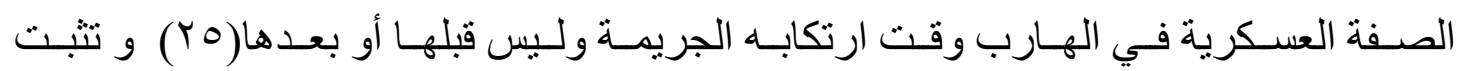

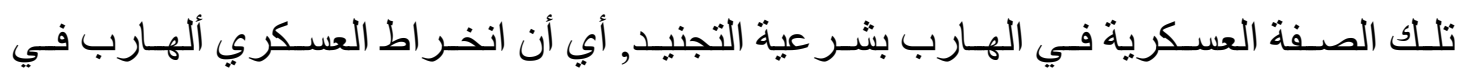

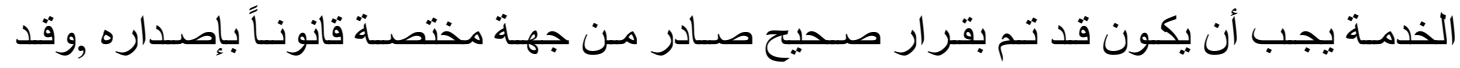
روعي فيه شروط الخدمة العكرية كالجنسية الوطنية و العمر و اللياقة البدنية.

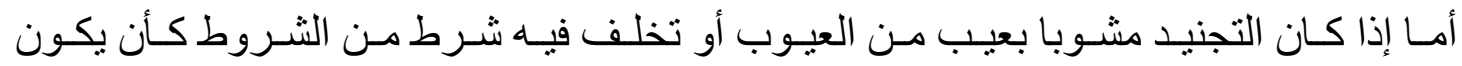

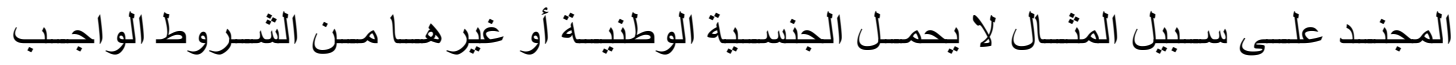

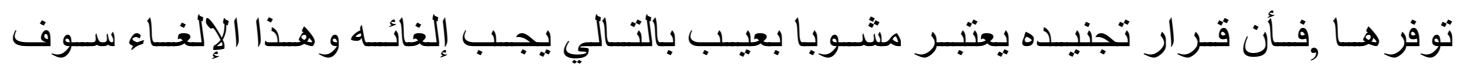

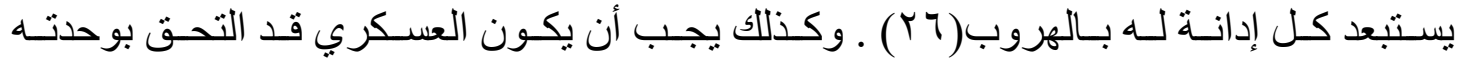




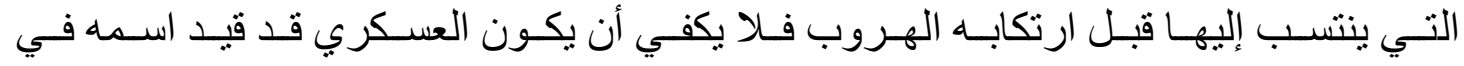
سجلات الوحدة بل لا بد من انضمامه للوحدة وقيد في سجلها.

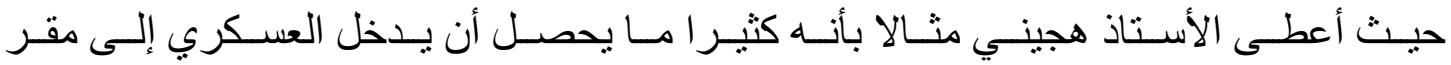
وحدتـهـ في المسـاء ولكـن يؤجـل قيـدهم إلـى الصـباح فـإذا انتهـز أحـدهم فرصـة الليـل واختفى

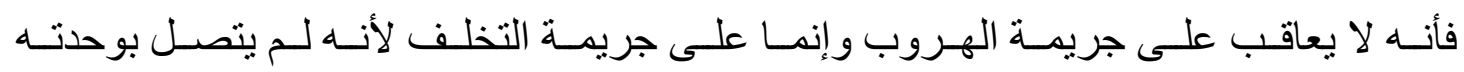
بعـد(YV) . و علـى الـر غم مـن أن القـانون اسـتلزم انخـر اط العسـكري الهـارب فـي الخدمـة

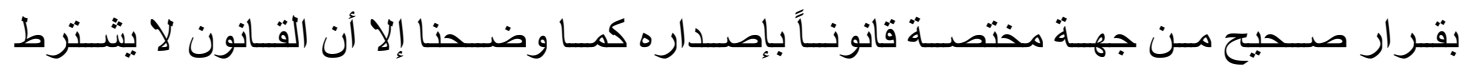
ألمباشـرة أو الخدمـة الفعليـة في القـوات المسـلحة ,كـأن يكـون العسـكري الهـارب في اجـازة

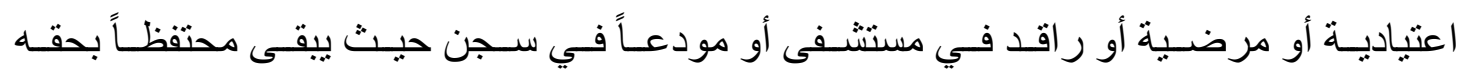

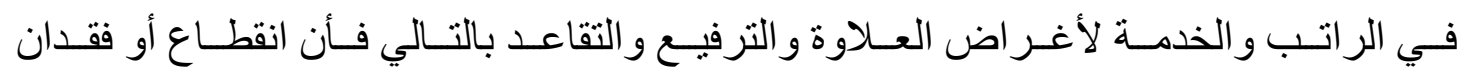
الصـفة العسـكرية لا يكـون إلا بإحـدى صـور إنهـاء الخدمـة كالإحالـة علـى التقاعـد أو الطـرد

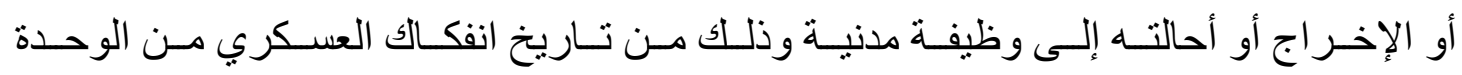

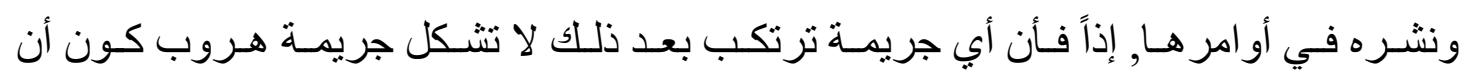
الصفة العسكرية غير متوفرة.

ولمعرفـة الاشـخاص الخاضـعين لأحكـام القـانون العسكري يـتم بـالرجوع إلـى المـادة ألأولىى

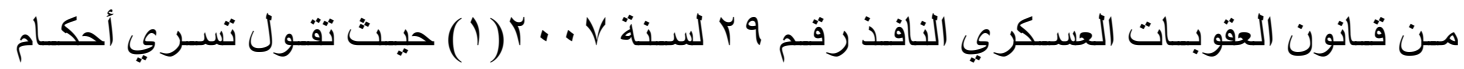
هذا القانون على:

أـمنتسـبـي القـوات المســلحة ألعر اقيـة المسـتمرين فـي الخدمـة عـن الجـر ائم المرتكبـة أثتـــاء الخدمة أو من جر ائها . أي ب-طلاب الكلية العسكرية وطلاب المعاهد و المدارس الخاصة بالجيش.

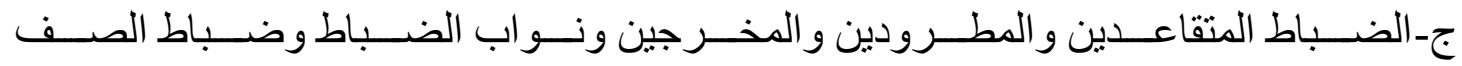
و الجنـود و المتقاعـدين أو المطـرودين أو المتسـرحين مـن الجـيش أو مـن الجـيش أو مـن أي قوة عسكرية أخرى إذا كان ارتكابه الجريمة قد تم إثناء الخدمة . دـألأسرى فيما يتعلق بالجر ائم التي يرتكبونها في المعتقلات. هـ-الضابط وضباط الصف و الجنود من الاحتياط المستمرين في الخدمة . 


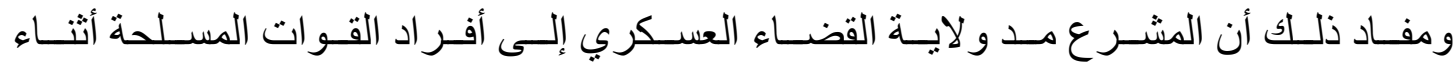

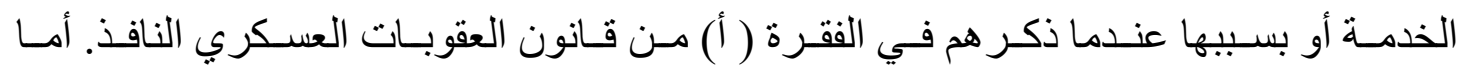

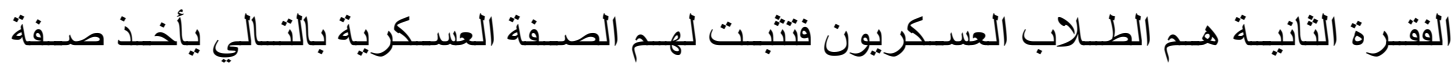

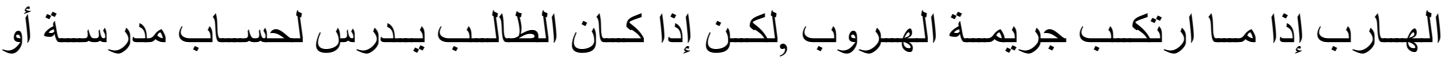

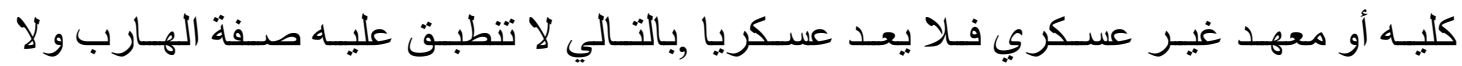

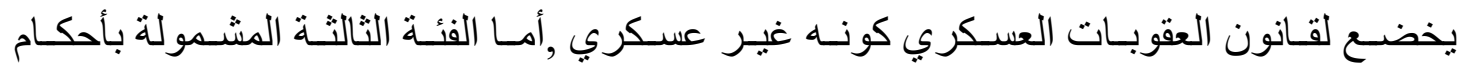
قـانون العقوبـات العسكري بالتـالي تنطبـق عليـهـ صـفة الهـارب إذا مــا هـرب ,العسـكريون

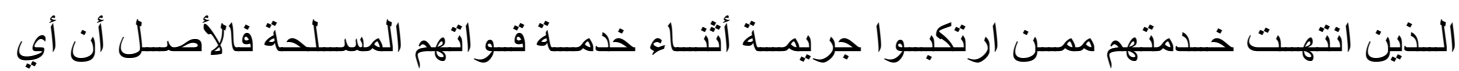

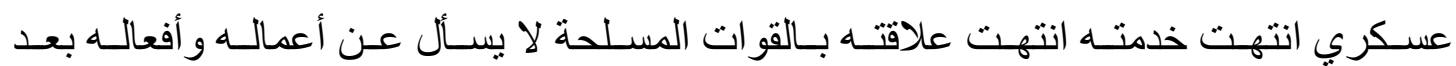

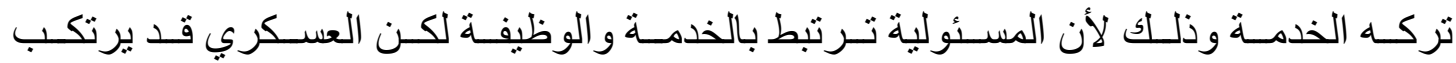

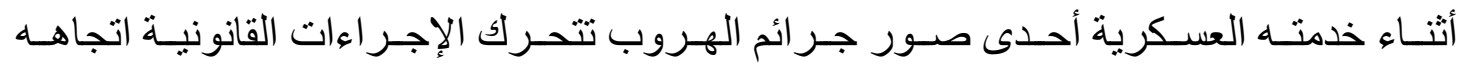

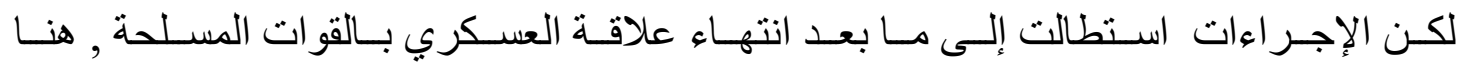

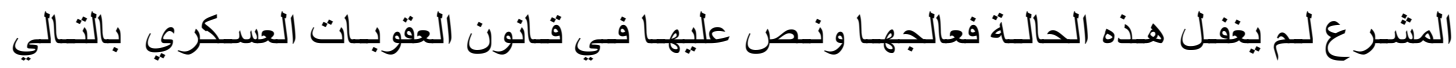
يحــاكم وتشـري عليـهـ العقوبـات المنصــوص عليـهـ فـي قــانون العقوبــات العسـكري لكـن

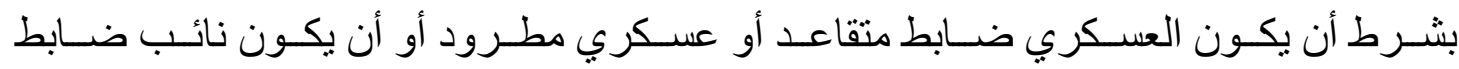

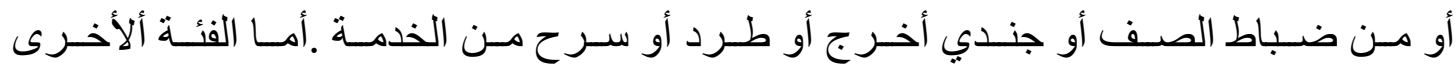

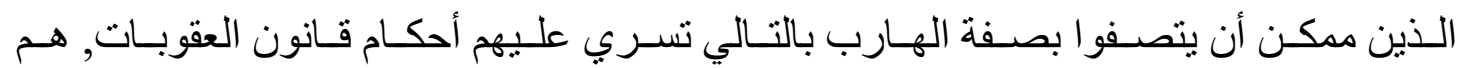

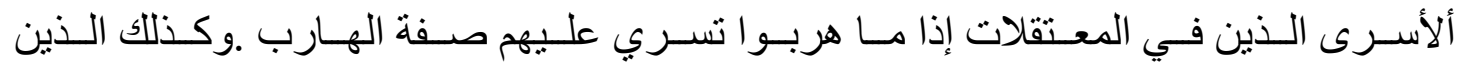
نصـت عليههم الفقرة (هـ) وهـم الضـابط وضـباط الصـف و الجنـود إذا مـا هربـوا يتصـفون

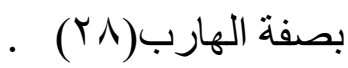

أمـا بالنسـبة للمشـرع المصـري فهو كالمشـرع ع العر اقي جعل فئـة مـن الأشـخاص خاضـعين

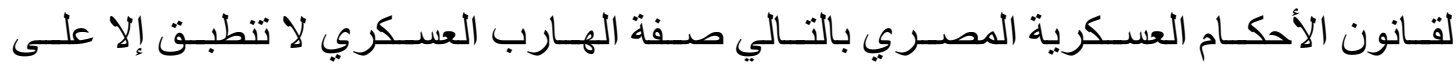

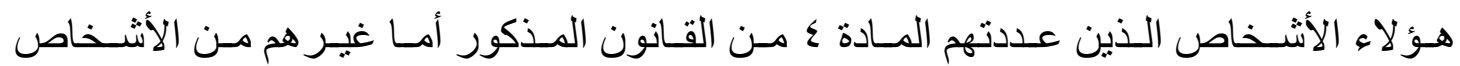

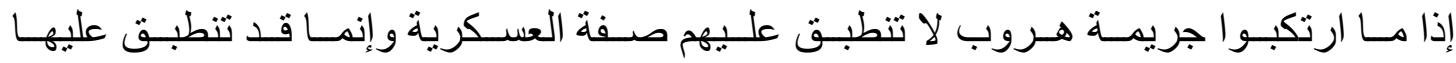

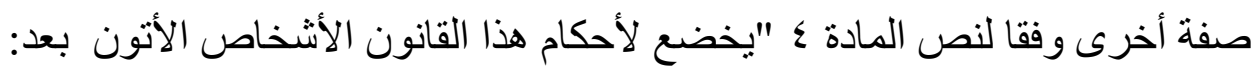
1 - ضباط القوات المسلحة الرئيسية و الفر عية و الإضافية r-ضباط الصف وجنود القوات المسلحة عموما 
rــلبة المدارس ومر اكز التدريب المهني و المعاهد و الكليات العسكرية

$$
\text { ع - أسرى الحرب }
$$

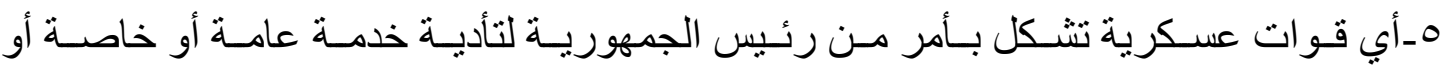
وقتنية

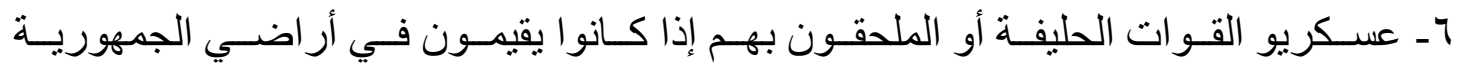

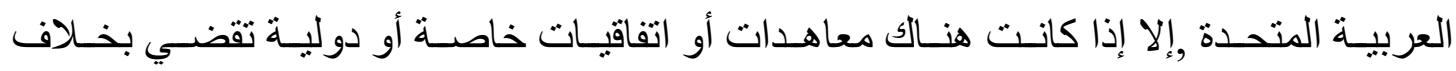
ذلك.

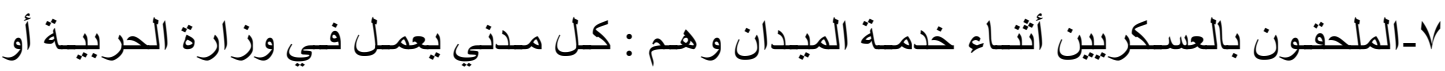

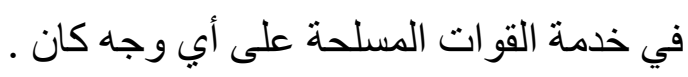

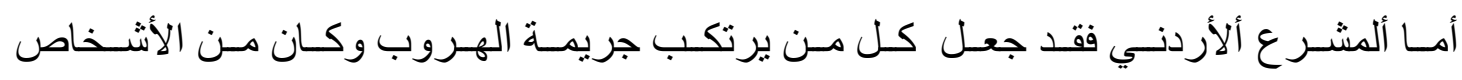

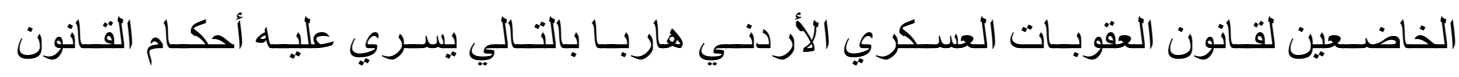

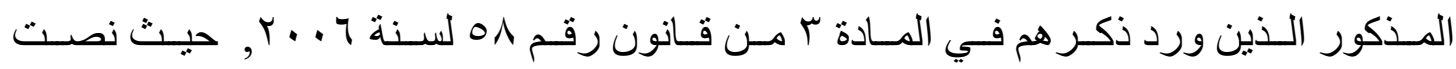
تسري أحكام هذا القانون على ما يلي :

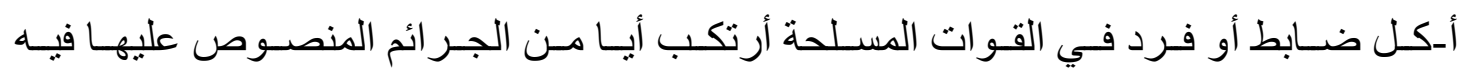
فاعلا كان أو محرضا أو متدخلا وأن فقد صفته العسكرية بعد ارتكابه تلك الجريمة

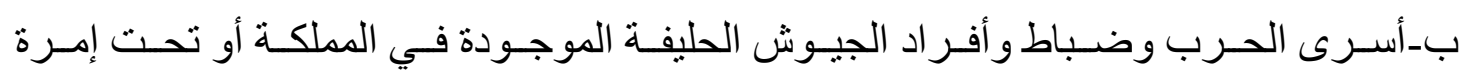
القوات المسلحة إذا ارتكبوا أيا من الجرائم المنصوص وصروس عليها فيه.

و عليـهـ أن صـفة العسكرية في جريمـة الهـروب هـي ركـن أساسـي في الجريمـة وهـو الـرأي

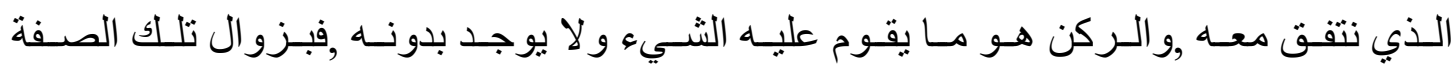

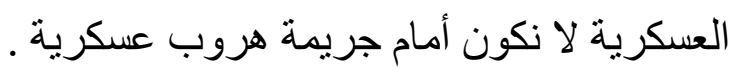




\section{(The third requirement) المطلب الثالث)}

\section{طبيعة جريمة الهروب ( The nature of crime)}

بمكـن تحديـد طبيعـة جريمـة الهـروب العسكرية مـن خـلال بيـان كـل مـن ذاتيتهـا

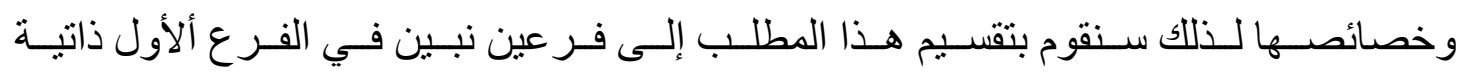

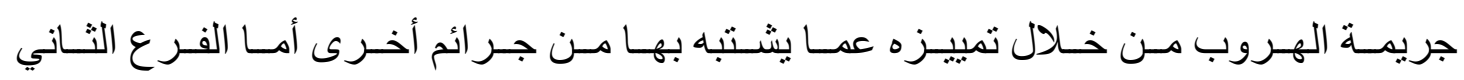
سنذكر فيه خصائص جريمة الهروب .

(Section I) (الفرع ألأول)

\section{ذاتية جريمة الهروب (Characteristics of fleeing crime)}

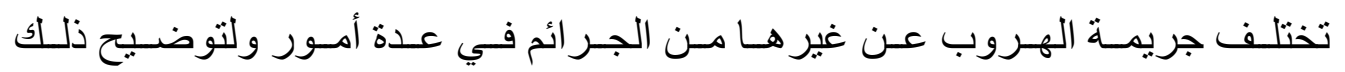

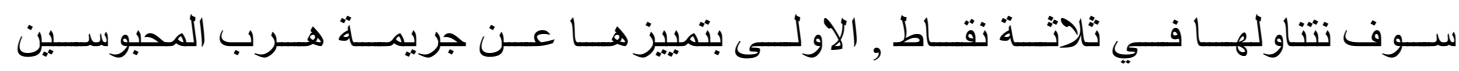

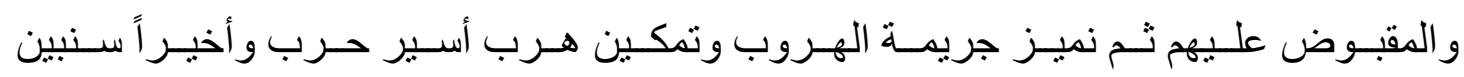
الفرق بينها وبين جريمة الغياب.

$$
\text { أولاً: الهروب وهرب المحبوسين والمقبوض عليه }
$$

تتميز جريمة الهروب عن جريمة هرب المحبوسين و المقبوض عليهم بما يأتي: ا ـمـن حيـث طبيعـة الجريمـة :جريمـة الهـروب مـن الجـر ائم العسكرية البحتــة التـي ترتكبـ

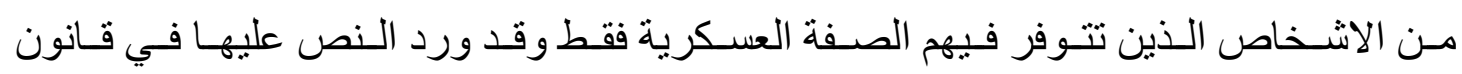

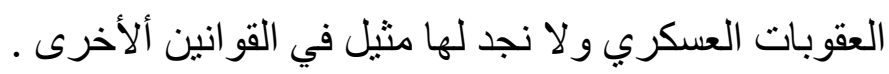

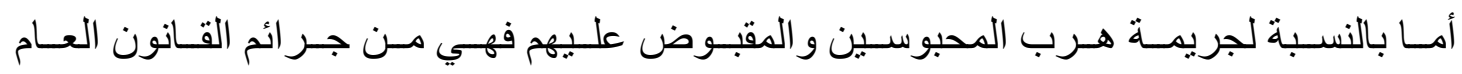

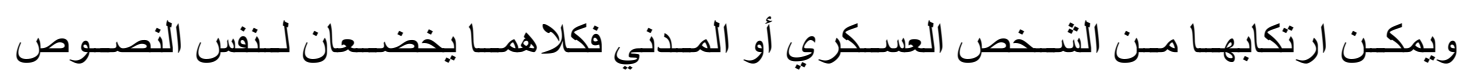

r ـ مـن حيـث اختصــاص المحكمـة فـي نظـر الــعوى: جريمـة الهـروب العسـكرية تنظـر

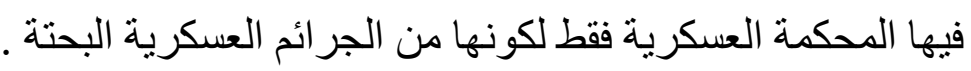


أمـا بالنسـبة لهـروب المحبوسـين و المقبوض عليهم ممكن أن تنظـر فيهـا المحكمـة العسكرية

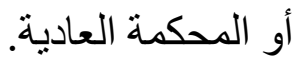

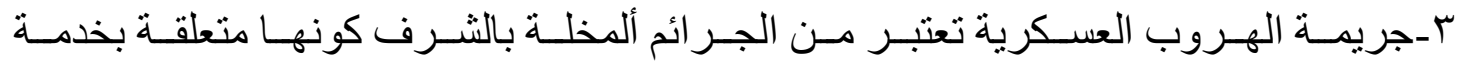
الوطن أما جريمة هرب المحبوسين و المقبوض عليهم فلا تعتبر من الجر ائم المخلة بالثرف.

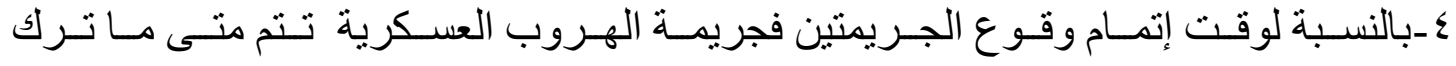

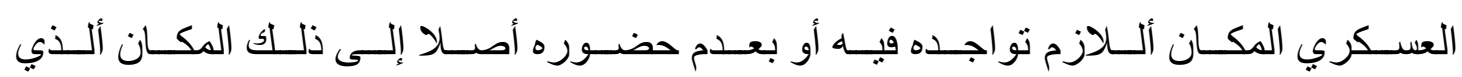
تفرضه عليه القو انين و الانظمة العسكرية.

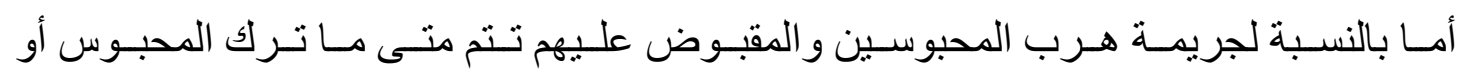

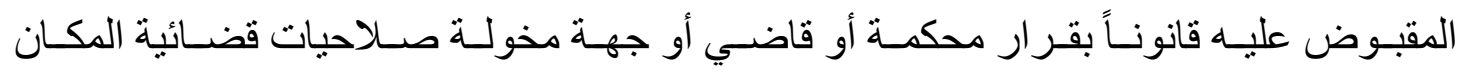
الذي قيدت فيه حريته إلى مكان أخر يصبح فيه حراً

ثانيا: جريمة الهروب وتمكين هرب أسير الحرب تتميز جريمة الهروب عن تمكين هرب أسير الحرب بما يأتي:

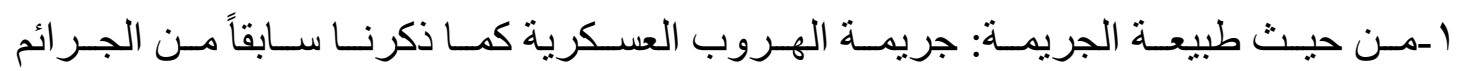

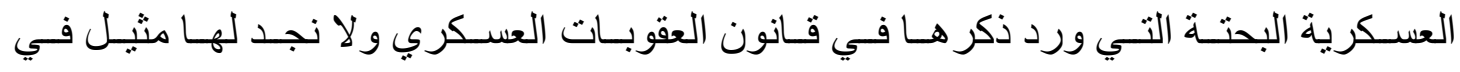
القو انين ألأخرى و الفاعل فيها شخص عسكري حقيقةً أو حكماً. أمـا بالنسـبة لجريمـة تمكين هـرب أسـير الحـرب فهـي مـن جـر ائم القـانون العـام (• (ب)ألتـي

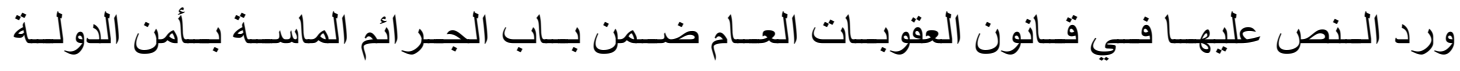

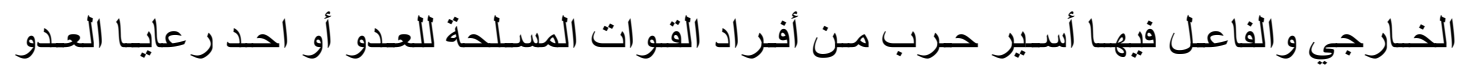
المعتقلين و الذين يحملون جنسية الدولة المعادية .

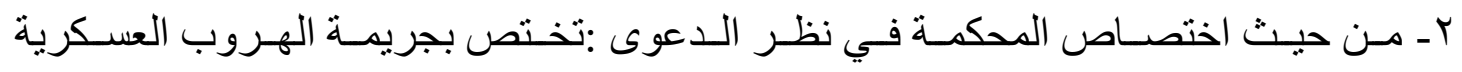

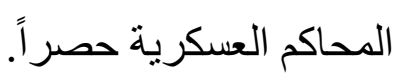
أما جريمة تمكين هرب أسير الحرب ممكن أن تنظر فيها ألمحاكم العسكرية أو العادية 


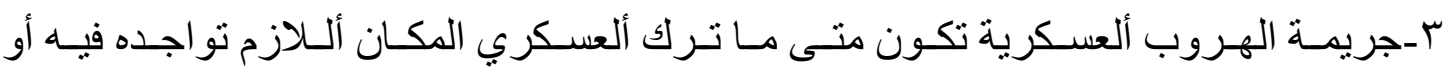

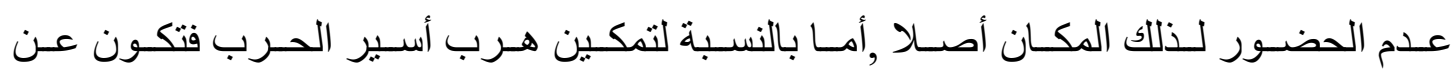
مغادرة الأسير المكان المسلوب حريته فيه .

\section{ثالثا: جريمة الهروب و جريمة الغياب العسكري:}

على الـر غم مـن أن الجـريمتين مـن الجـر ائم العسـكرية ألبحتـــة التـي ورد الــص عليهـا فـي

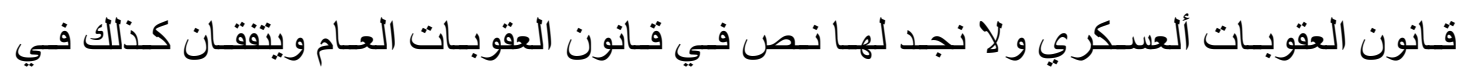
أنهما يرتكبان من الثخص العسكري حصر اً إلا أنهما يختلفان فيما يأتي:

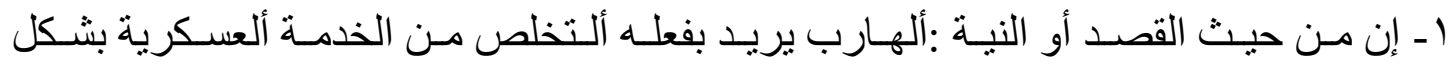

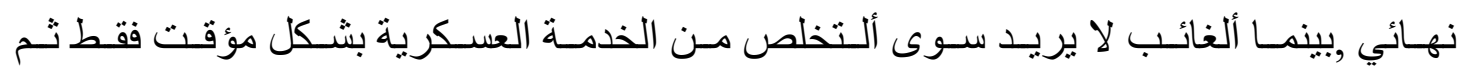

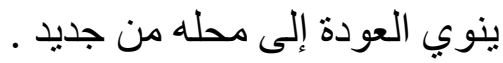

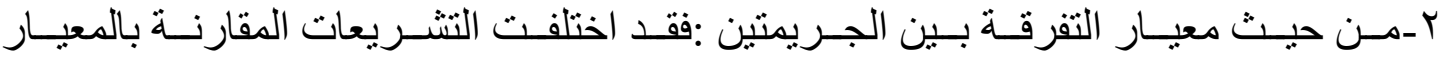

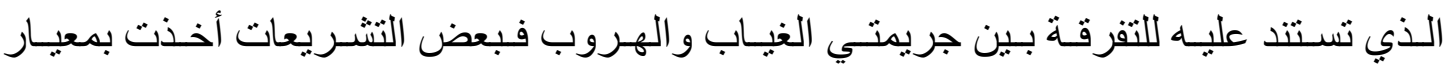
الإمهـال و الإمهـال يعنـي أن يحـد القانون مـدة يعتبـر بموجبهـا العسكري غائبـاً فـإن تجـاوز

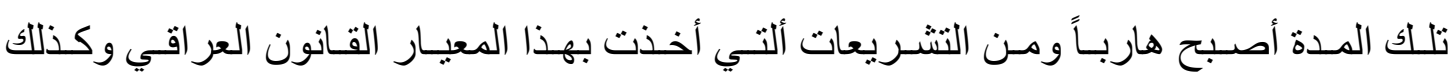

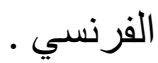

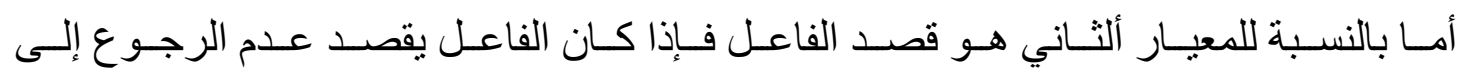
الخدمة بشكل نهائي يعتبر هارباً.

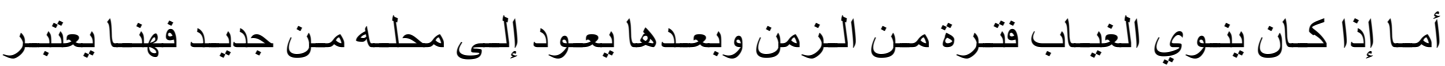

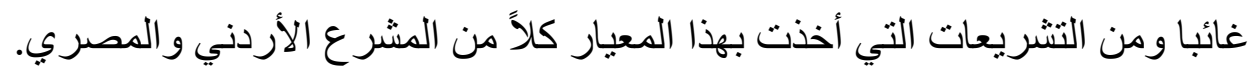




\section{( الفرع الثاني (Section II) - ( )}

\section{خصائص جريمة الهروب (Characteristics of fleeing crime)}

من البحث في جريمة الهروب العسكرية تبين أنها تتميز بما يأتي :

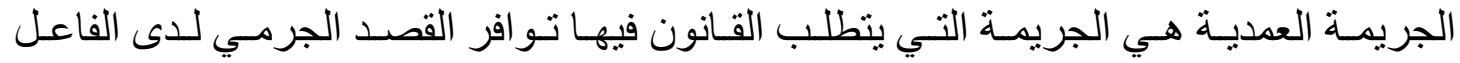

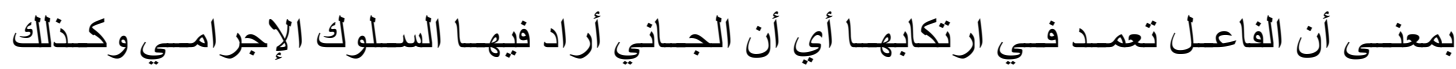

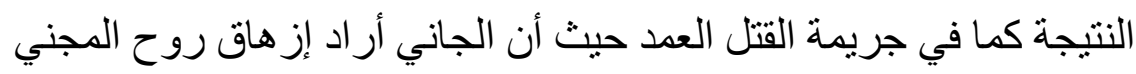

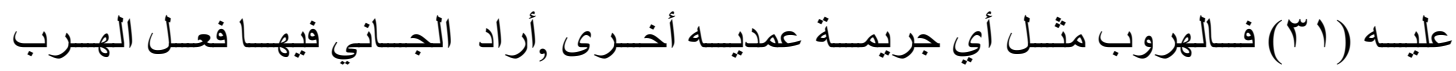

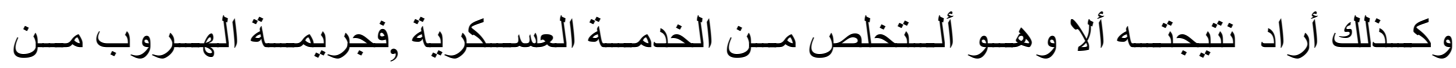
الجرائم التي لا يتصور أن تحدث بصورة الخطأ أنما بصورة العمد فقط.

\section{ثَانيا: الهروب من الجرائم ذات السلوك الايجابي والسلبي}

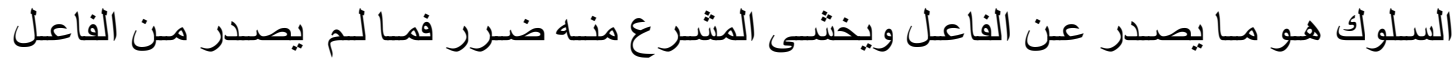

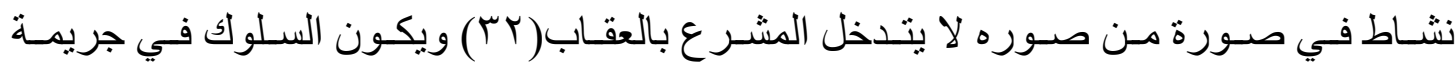

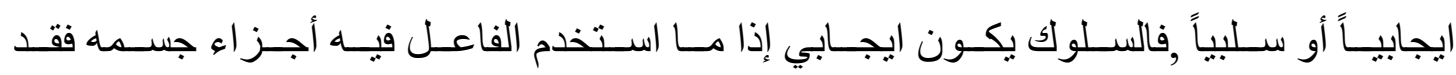

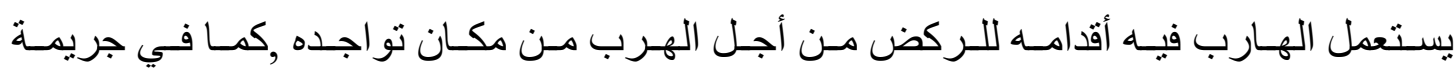

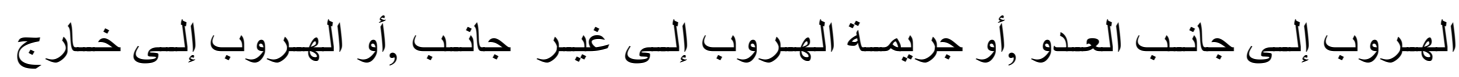

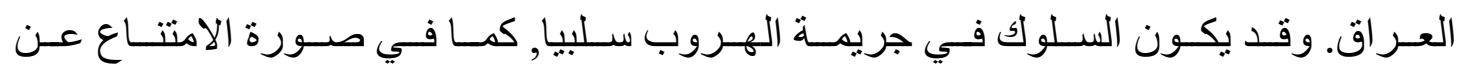

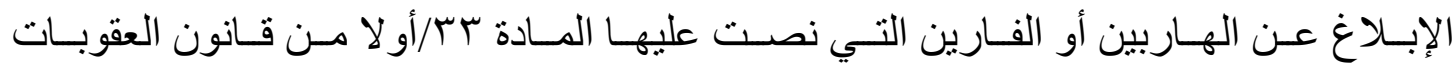

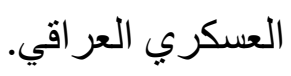

\section{ثالثا: جريمة الهروب جريمة عسكرية بحتة}

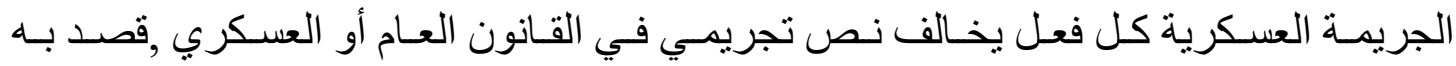

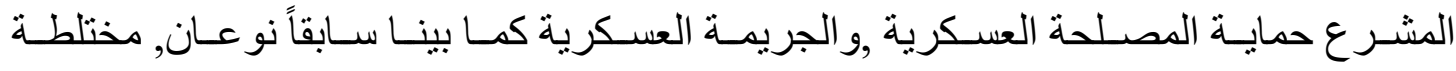

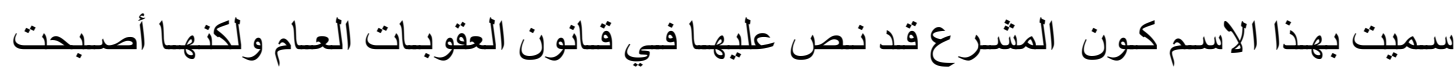

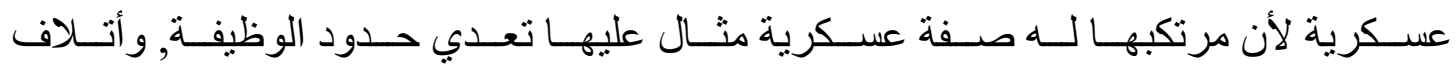

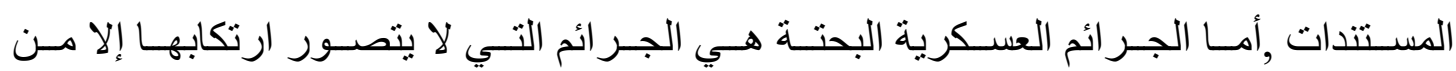


العسـكريين , فهـي تقـع بالمخالفـة لأحكـام النظــام العــكري , وكــللك الو اجبـات العسـكرية

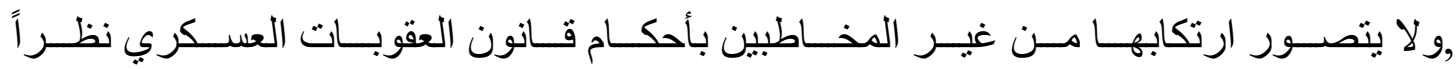

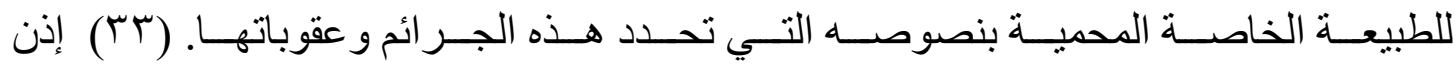

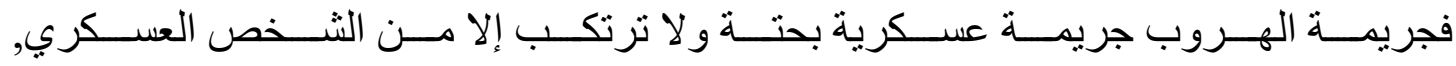
ومنصوص عليها في قانون العقوبات العسكري.

\section{رابعا: جريمة الهروب من الجرائم الشكلية}

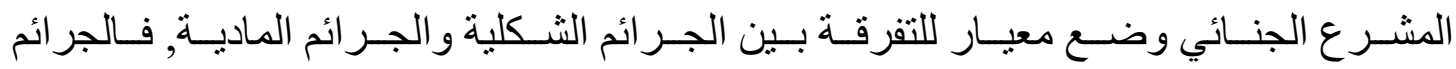
الماديـة هـي الجريمـة التـي يشــرط القـانون لوجودهــا ضـرر مباثـر ويفترض فـي الفاعـل

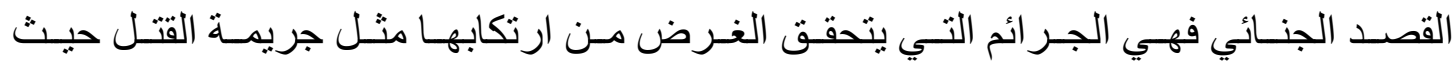

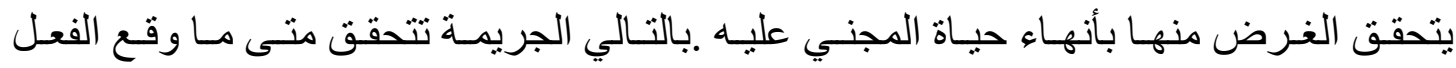

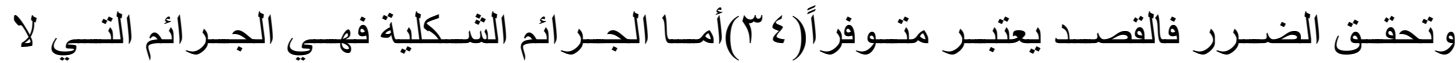
تتططلب تحقيـق الغـرض الـذي أر اده الفاعـل مـن ارتكــاب بمعنـى أن مجـرد ارتكــاب الفاعـل للفعـل الـــي يعـد جريمــة تتحقـق الجريمـة, وكـذلك يسـتحق العقـاب ومنهــا جريمـة الهـروب فبمجرد ارتكاب فحل الهرب يعاقب الفاعل وأن لم يحقق غرضه المقصود من الهروب.

\section{خامساً: جريمة اللهروب جريمة مستمرة}

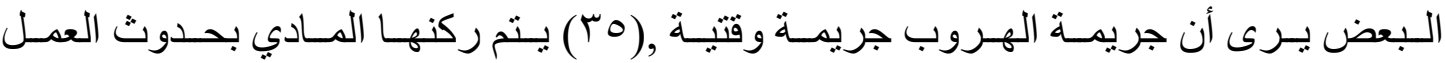

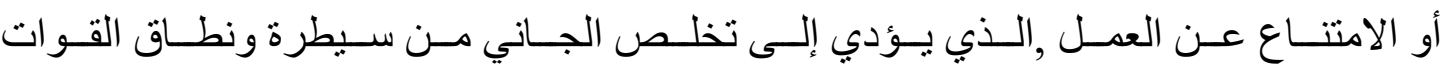
المسـلحة وتعتبـر النتيجـة في هـذه الحالـة نتيجـة وقتيـة كون الجريمـة قد حـثت في وقت

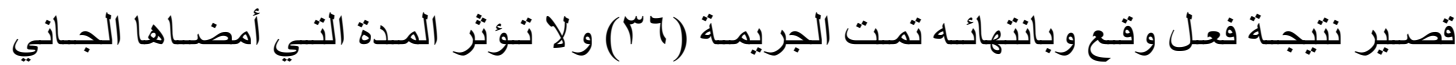
هاربـاً في تغييـر نـوع الجريمـة, وتبقى جريمـة وقتيـة حتى وأن طـال هروبـهـ أثـهر حيـث أن

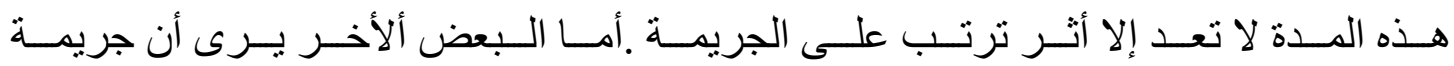
الهـروب, جريمـة مسـتمرة رحيـث يظـل الجـاني مرتكبــا للجريمـة في كـل وقـت ينقطـع فيـهـ

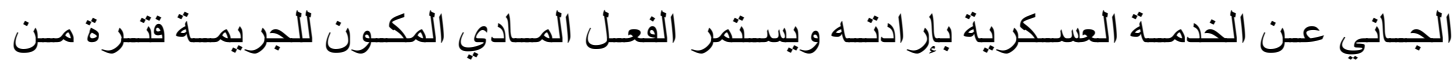

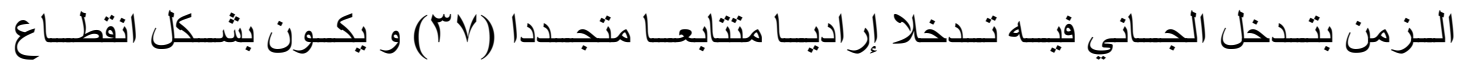

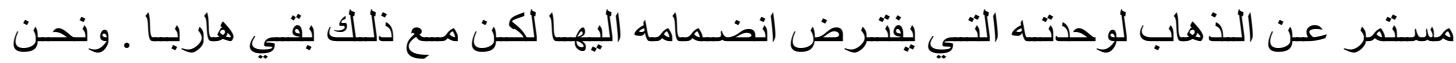

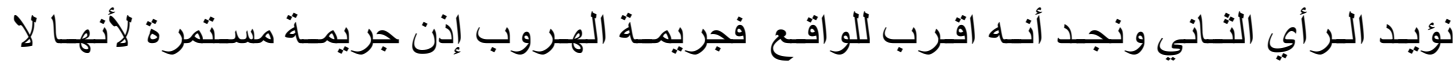
تتوقف إلا إذا توقف الهارب تلقائيا او إذا قبض عليه إثناء هروبه . 


\section{(The second topic) المبحث الثاني}

\section{موضع الهروب في القانون ( The legal concept of the crime)}

القـانون ظــاهرة اجتماعيـة مرتبطــة حلقاتهـا بالماضــي وهـو فـي الحاضـر لا يمكـن

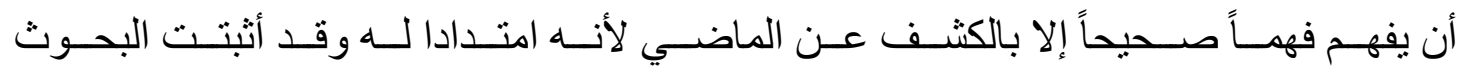

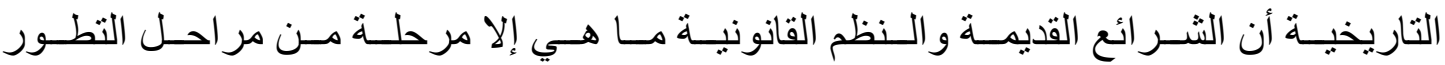

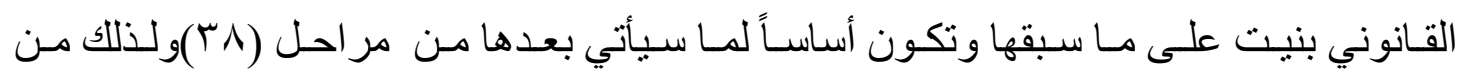

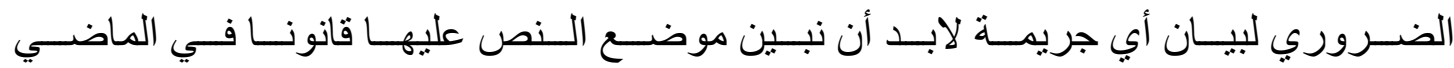
و الحاضـر ومـن ثم بيـان موضـع النص عليهـا في التشـريعات المقارنـة لذلك سـنقوم بتقسـيم

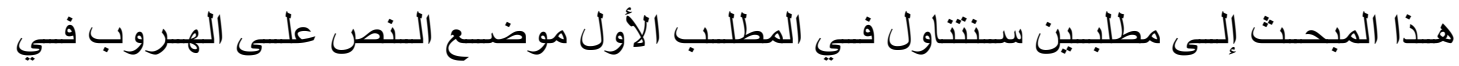

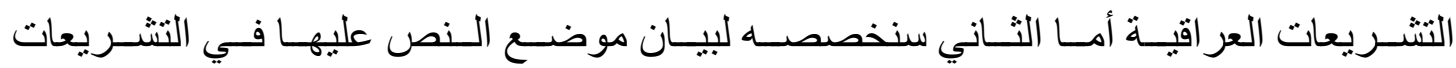

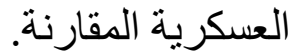

\section{المطلب الأول (The first requirement)}

\section{موضع النص على الهروب في التشريعات العراقية The crime of fleeing in the}

\section{Iraqi legislations)}

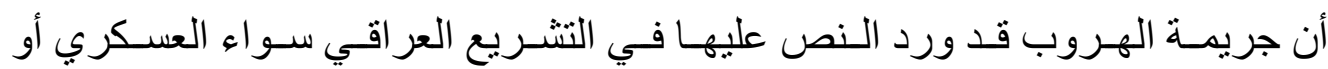

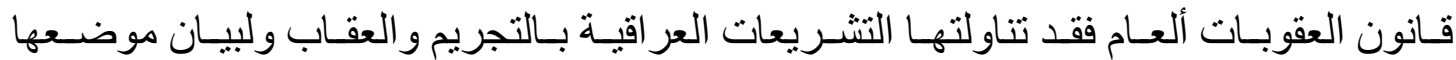

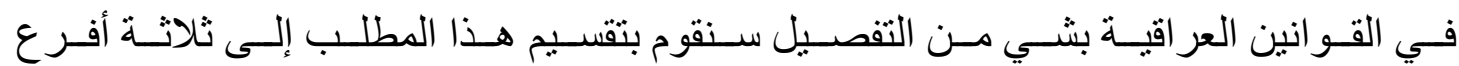

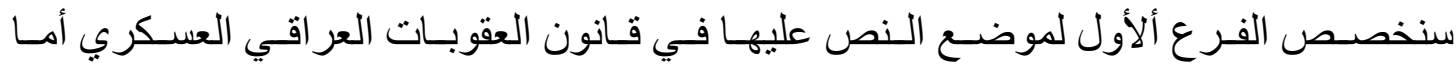

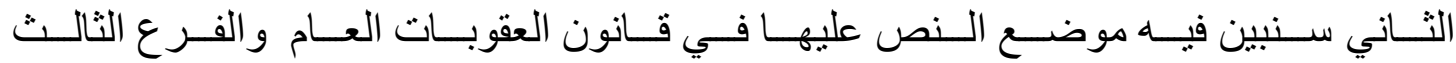
سنخصصه لموضع النص على الهروب في قانون معاقبة الهروب إلى الخارج. 


\section{(section I) (الفرع ألأول}

\section{موضع النص على الهروب في التشريعات العكرية العراقية}

\section{The crime of fleeing in Iraqi military legislations}

ولم تعرف العصور السابقة في القدم قانونا عسكريا للعقو بات و ايضا لم تكن تعرف نظام المحاكم العسكرية فمنذ انشاء الجيوش كانت صلاحيات القاضي العسكري تمنح لذات القائد

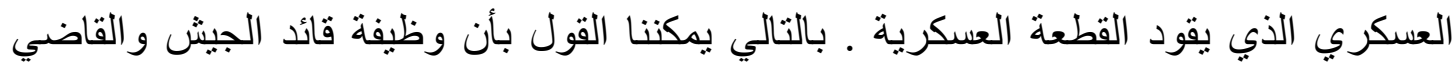
العسكري موضو عة في يد شخص و احد(؟)). وفي العر اق طبق قانون الجز اء العسكري العثماني على قطعات الجيش العثماني الموجود في العراق قبل تأسيس الجيش العر اقي ,لأن العر اق اعتبر

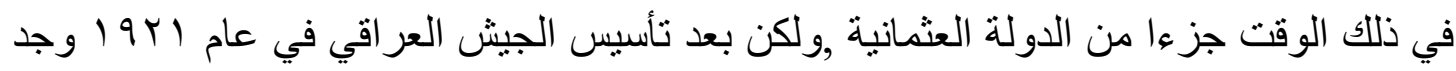
الميجر جنرال برسي كوكس القائد الانكليزي في العراق ضرورة وضع احكام لتنظيم الجيش العر اقي إلى أن يسن قانون دائمي فصدر منشور الجيش العر اقي الذي نص في المادة الاولى منه ( (1) على سريان القانون من حيث الزمان و المادة الثانية (؟) تناولت التعاريف و السادسة خصصها

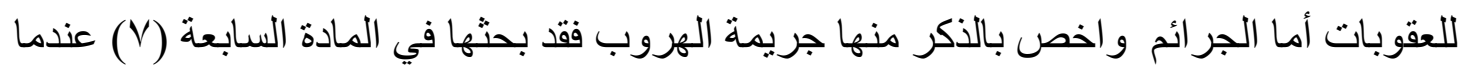

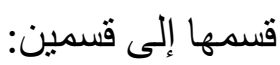
أ-جر ائم اسماها بالكبيرة وهي الهروب والعصيان والاعتداء

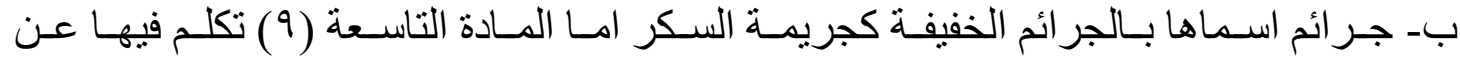

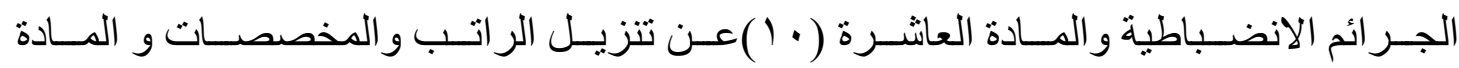

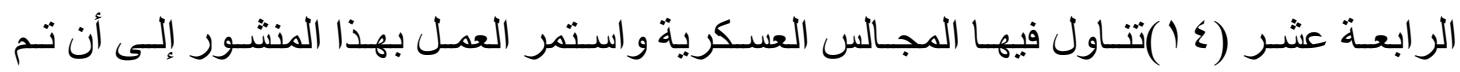

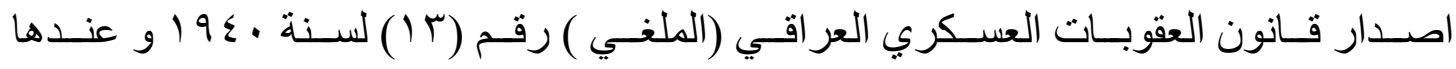

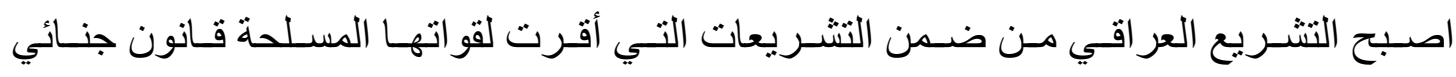

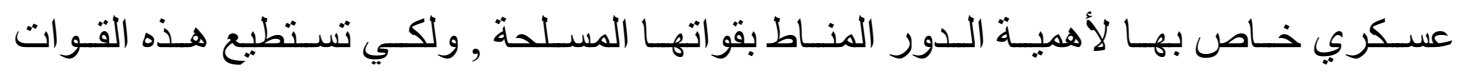

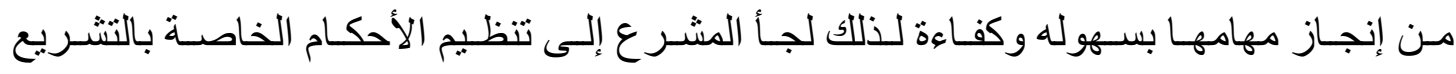

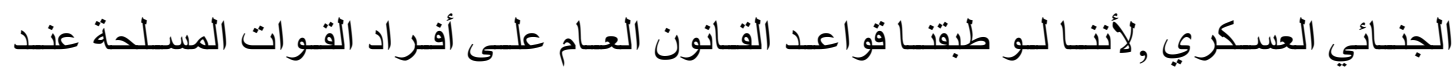

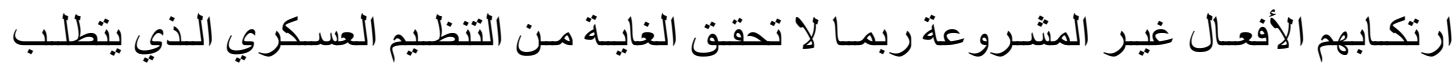

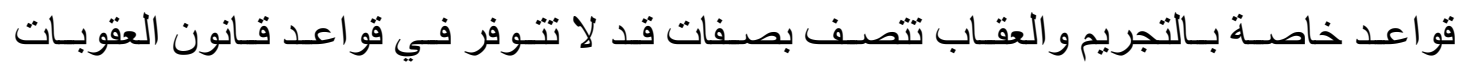


للذلك نـرى هو أفضـل حل لـللك هو خصـها بتشـريع جنـائي خـاص ـ و هنـا سـنقوم بتقسـيم هذا الفرع إلـى ثنلاثـة نقـاط نبـين موضـعها في كـل مـن قـانون العقوبـات العسـكري الملغـي رقم

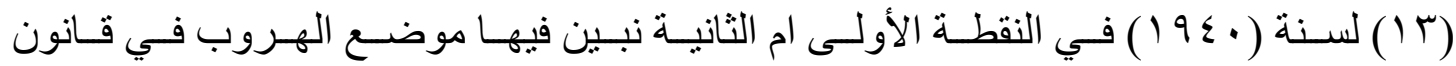

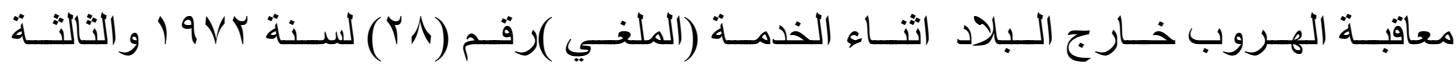
نتتـاول فيهـا موضـع الـص على الهـروب في قـانون العقوبـات العسـكري النافـذرقـم (9 ( )

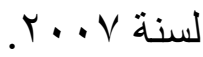

\section{أولاً: موضع الهروب في قانون العقوبات العسكري الملفي رقم (س I) لسنة م ـ 19}

بصـدور قـانون العقوبـات العسكري رقـم سا لسـنة ، ـو ا فقـد اعـاد القـانون تنظـيم الاحكـام الخاصـة بـالهروب حيـث افـرد الفصـل الثالث مـن القسـم الثـاني لجـر ائم الغيـاب و الهـروب في

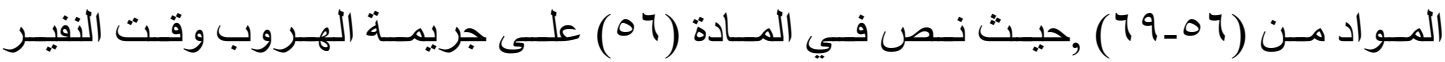
بـالحبس مـدة لا تزيـد علـى ( • ()ســنوات و اجـاز الحكـم بالإعـدام إذاز ادت عـن ثلاثـة ايـام

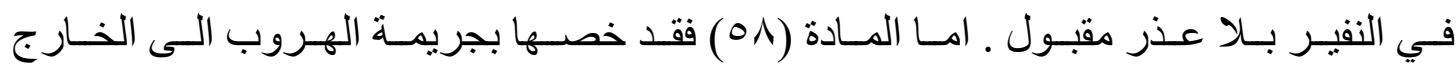

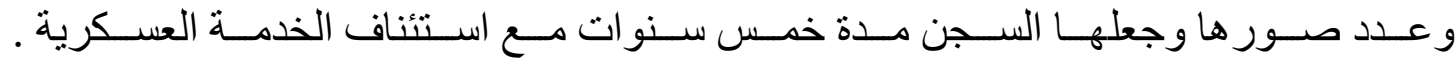
وتتـاول في المـادة (90) كـلا مـن جريمـة الهـرب الـى جانـب العـدو وجعـل عقوبتهـا الاعـدام و الهـروب الـى غيـر جانــب العـدو لكـن عنـد مجابهـة العـدو او مـن موقـع محصــور وجعـل

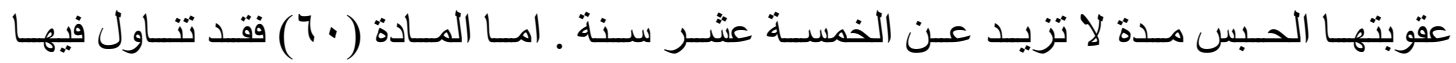
الاتفـاق على تهريـب اكثـر مـن شخصـين الـى دولـة اجنبيـة وجعـل عقوبتهـا الحـبس مـدة لا

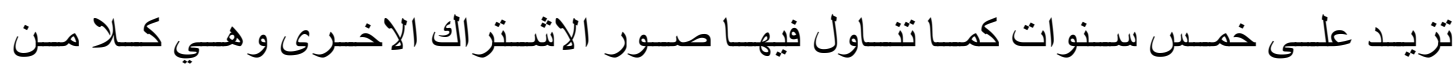
التحـريض و المســاعدة ـ و اجـاز كـذلك فـي المـادة(r T) تأجيـل عقوبـة الهـاربين بعـد اكمـالهم الخدمـة وخفض عقوبـة الهـارب النـادم مـن الاعـدام الـى الحبس الثــديد مـدة لا تزيـد على

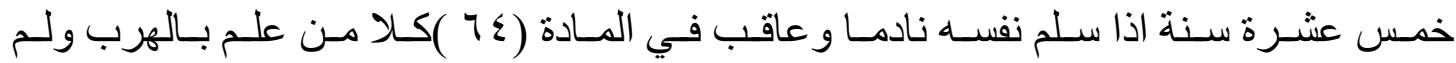

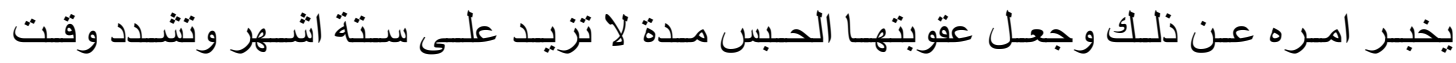
النفيـر الـى مـدة لا تزيــد علـى سـنتين. وتنـاول فـي المـادة (70 ) المســاعدة علـى الهـروب

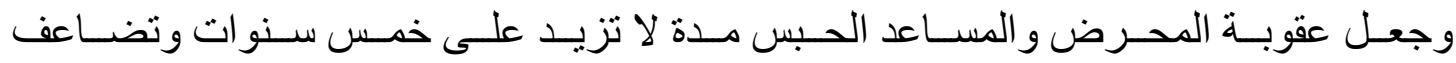

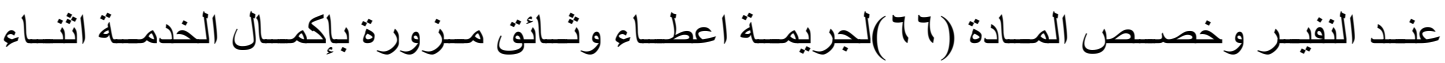

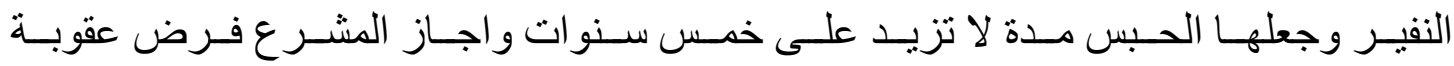
الاعدام في حال تكر ار ها. 


\section{ثانيا موضع الهروب في قانون العقوبات العكري الناقذ رقم (9 1 ) لسنة (V . . r)}

مشـرعنا العسـكري خـص القوات المسـلحة بتشـريع جنـائي خـاص فيهـا ونـص على جريمـة

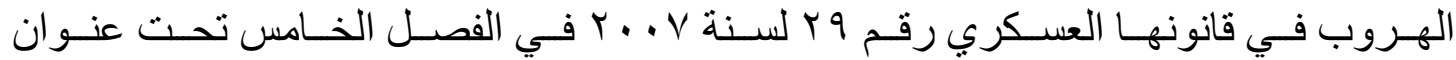

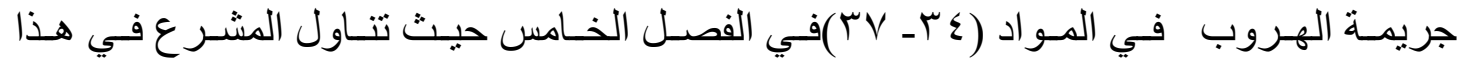
الفصــل جريمــة الهـروب مبينـاً صــور ها و عقوباتهــا و الظــروف المخفــة و المشــدة الخاصــة بتلك الجريمة.

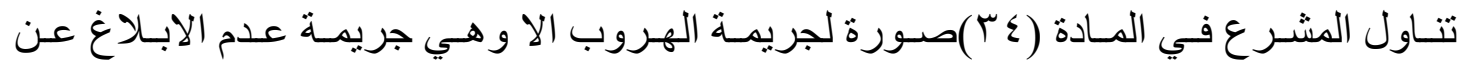
الهاربين وجعل عقوبتها الحبس لمدة لا تزيد على سنة واحدة

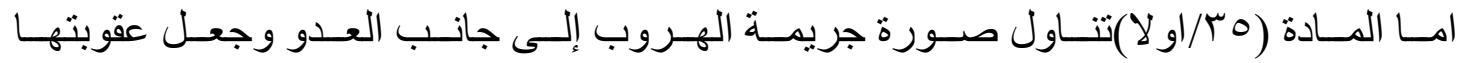
الاعـدام بشـكل مطلـق دون أن يحـدد معهـا أي عقوبـة اخـرى ,فلـم يشـترط فـي هـذه الصــورة أن يكـون ارتكابهـا فـي ظـرفٍ معـين أو وقـت معسين أو لغـرض معسين طالمـا كـان الهـروب

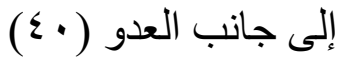

وخصـص المـادة (هب/ثانيـا) لجريمـة الهـروب إلـى غيـر جانـب العـدو عنـــ مجابهـة العـدو أو

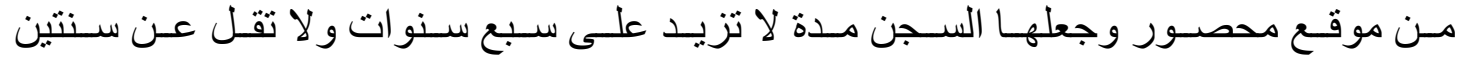
وتتـاول فـي المـادة (هب/ثالثـا) صـورة الهـروب إلـى داخـل حـدود العـر اق وجعلهــا الحـبس

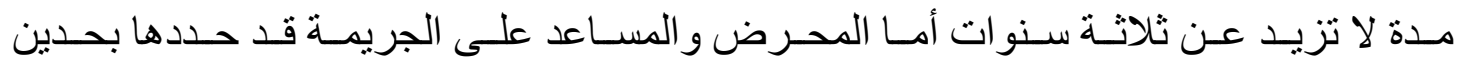

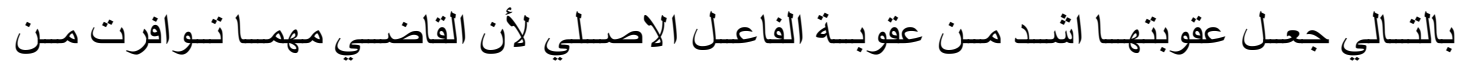
اسـباب لا يسـتطيع أن ينـزل عـن السـنة وتكلـم فـي المـادة (هـ/ر ابعـا)عن جريمـة التهريـب بالاتفـاق اكثـر مـن شخصـين وجعلهــا الحـبس بصــورة مطلقـة دون أن يحـدد حـدين ادنـى

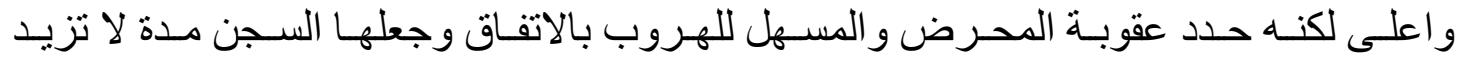

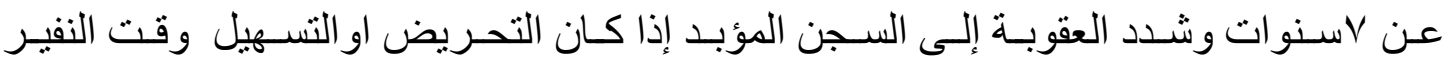

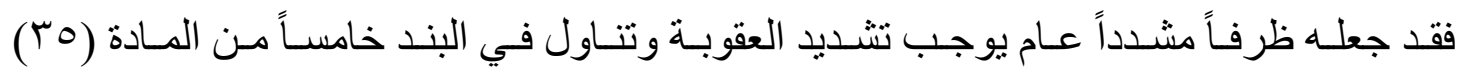
عـدة صـور للجريمـة وهـي كـلا مـن جريمـة الهـروب الـى الخـارج إثتـاء سـريان مـدة الخدمـة

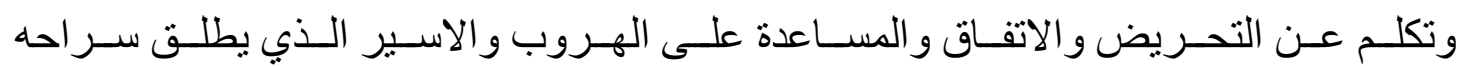

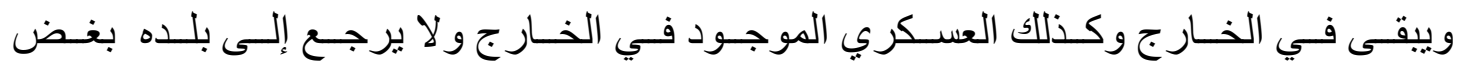
النظـر عـن سـبب وجـوده في الخـارج بإجـازة أو مهمـة رسـمية وجعل عقوبـاتهم الحبس لمـدة خمس سنو ات فقط دون ان يحدد لها حدين 
امـا البنــ السـابع مـن المـادة (ب0) فقد خصـها لجريمـة الثـروع في ارتكـاب جريمـة الهـروب إلى الخارج وجعلها الحبس مدة لا تزيد عن سنتين

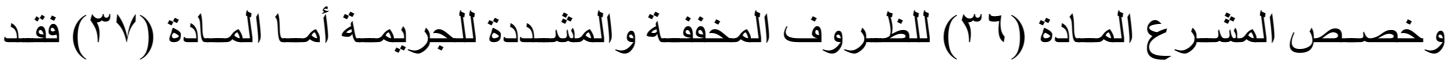

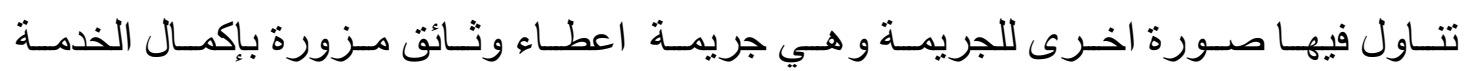

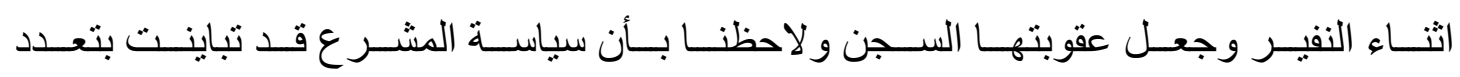

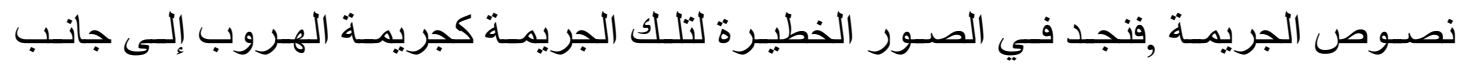

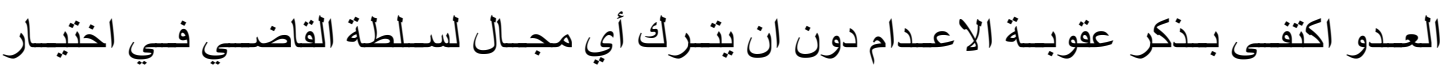

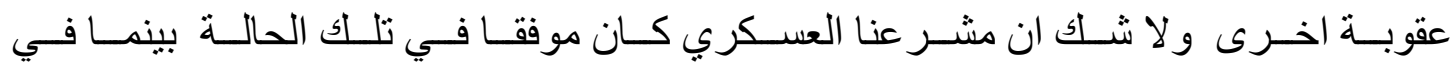

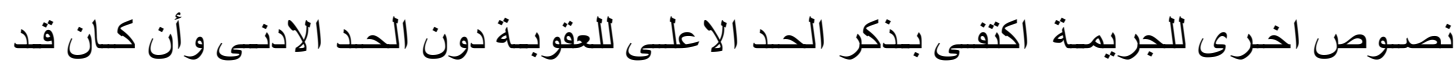

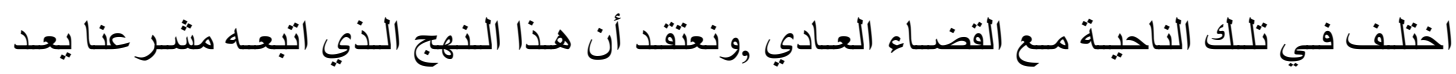

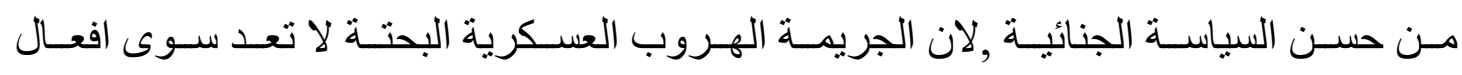

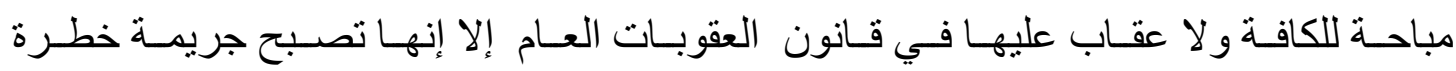

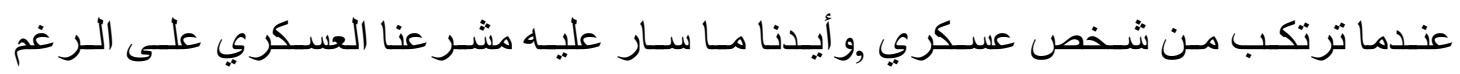

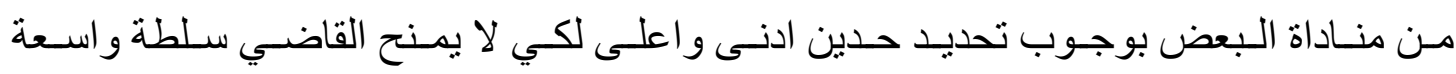

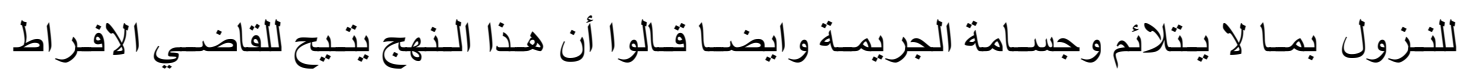

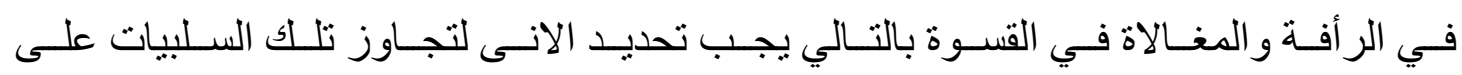

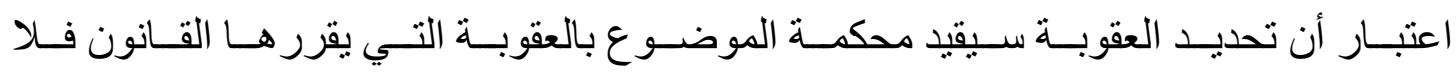

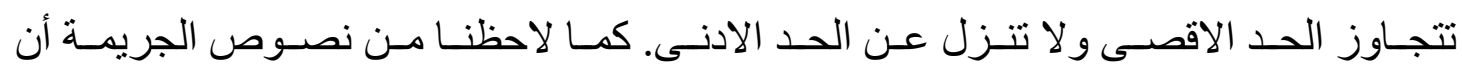

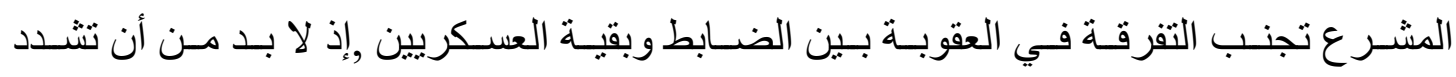

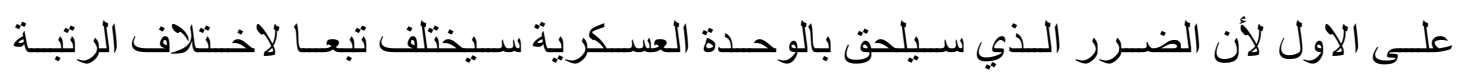

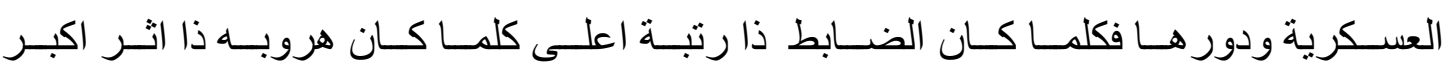

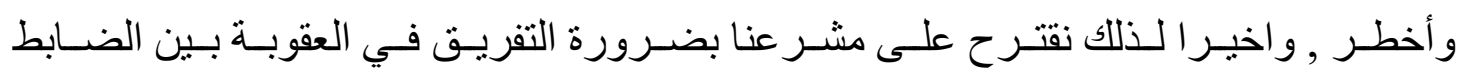

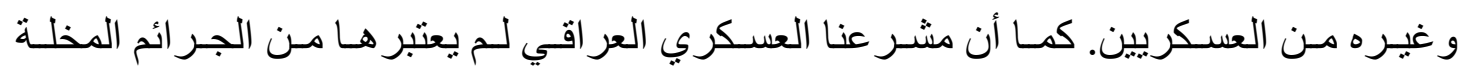

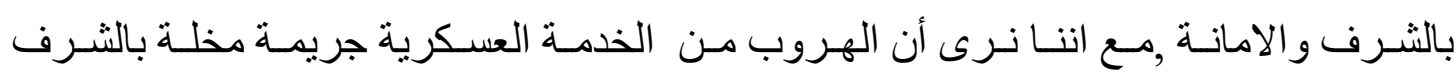

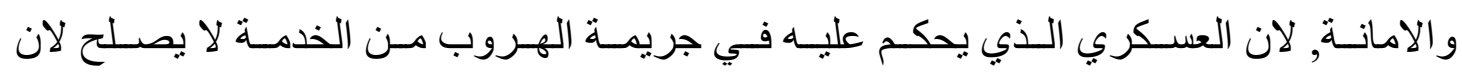

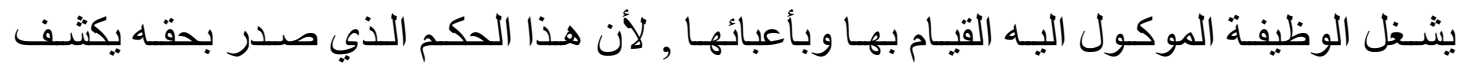

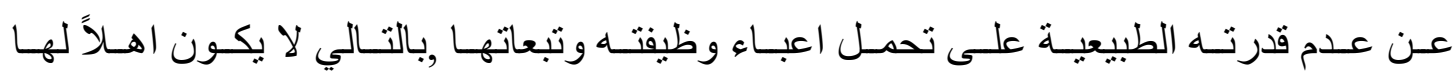

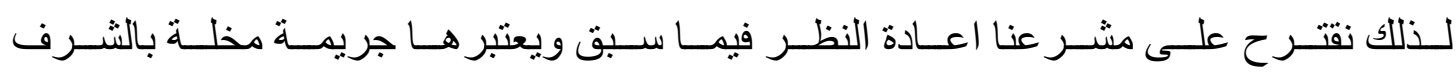


و الامانـة ,فقيمـة الجيش لا تكمن بعدده فقط بـل بو لائهه وتجهيزه ,فالتمسـك بالعناصـر غيـر الكفـؤة فـي القــوات المسـلحة يــؤثر سـلبا فـي كفــاءة القــوات المسـلحة ويضـــر بالمصــلحة العسكرية اولاً و اخراً

ثالثـا: موضـع النص على الهـروب في قـانون معاقبة الهـروب خـارج البلاد إثــاء الخدمـة

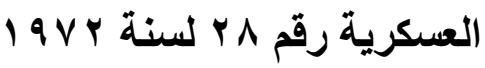

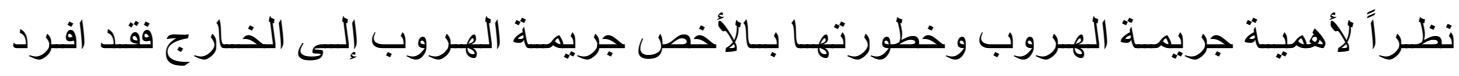
المشـرع الجنـائي تشـريع جنـائي خـاص فيهـا ,تمثـل بقـانون معاقبـة الهـروب خـار ج الـبلاد

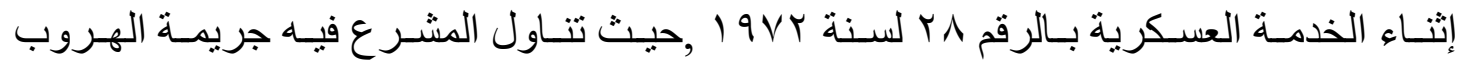
خـارج الـبلاد إثتـاء سـريان الخدمـة العسـكرية في نصوصـه التـي تتـألف مـن مـادتين فقط , ر حيـث خصـص المـادة ألأولـى للجريمـة السـالفة الــكر مـع بيـان صـور ها عنـدما نـص فيهـا

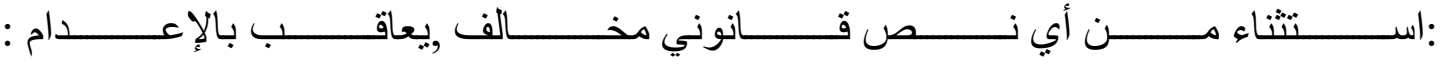
أـكـل عسـكري يهـرب خـار ج حـدود الجمهوريــة العر اقيـة إثتـاء سـريان خدمتـهـ العسـكرية بـكـل عسـكري يضـبط فـي حالــة الثـروع بارتكـاب جريمـة الهـروب المنصـوص عليهـا في الفقرة ( أ ) السابقة.

ج-كـل مـن اشـترك مـع الفاعـل أو حرضـهـ أو أغـر اه على ارتكـاب الجريمـة المـذكورة روكل من ساعد الفاعل أو آو اه أو أخفاه بقصد تسهيل هروبه وهو عالم بصفته وغرضه.

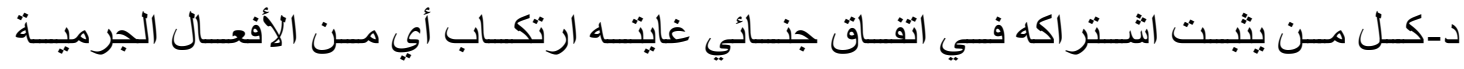

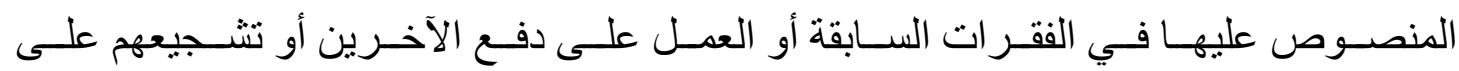

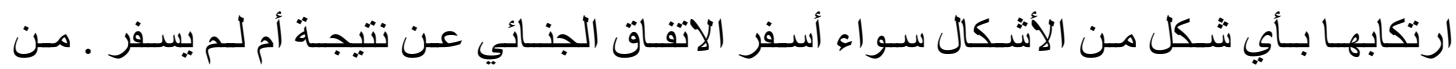

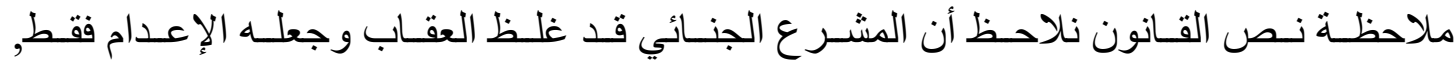

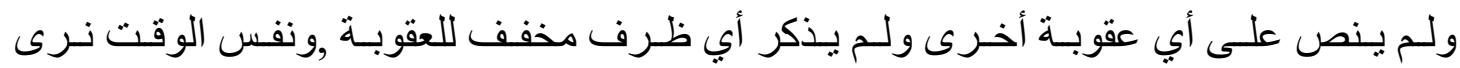
أنـهـ سـاوى بـين الفاعـل و الثـريك في العقوبـة أيـاً كانـت الوسـيلة التي اسـتعملها في الاشـتر اك

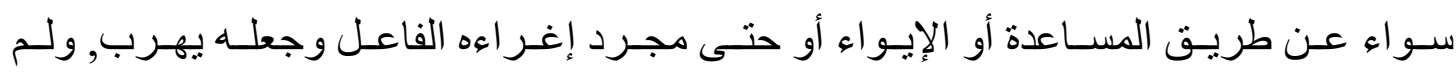
يجعـل لكـل منهمـا عقوبـة مختلفـة فجعـل الإعـدام إذا مـا ارتكـب جريمــة الهـروب كمــا انـهـ

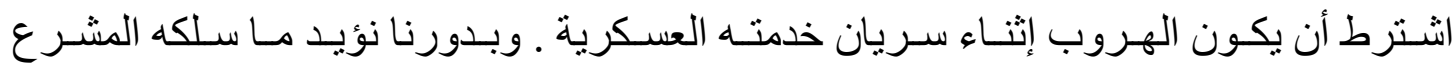


العر اقـي فـي القـانون المـذكور مـن ناحيـة تثــيده للعقوبـة ومســاو اته الفاعـل و الثــريك فـي العقـاب لخطورتهـا وخصوصـيتها عـن الصـور الاخـرى للجريمــة, ونقتـرح ضـرورة تفعيلـهـ

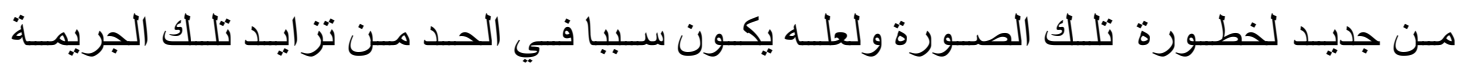
وردعها.

\section{(section II ) (الفرع الثاني ()}

\section{موضع النص على الهروب في قانون العقوبات}

\section{Fleeing crime in the penal code}

نــــ المشـرع العر اقـي علـى الهـروب تحــت عنــوان الفـرار فـي قـانون العقوبـات

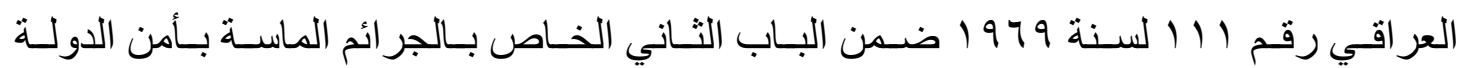

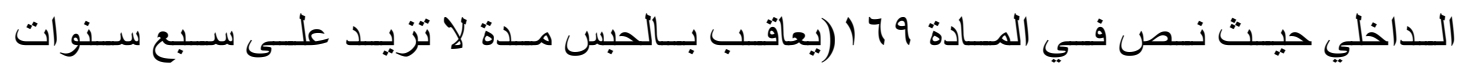

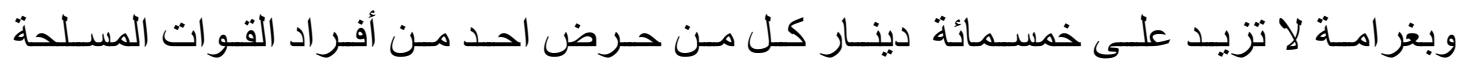

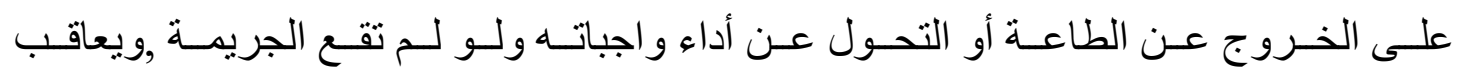

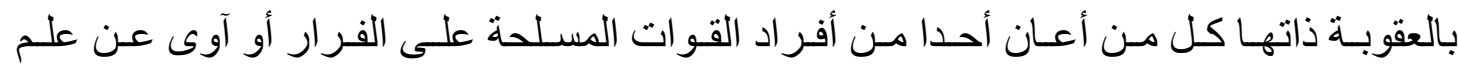

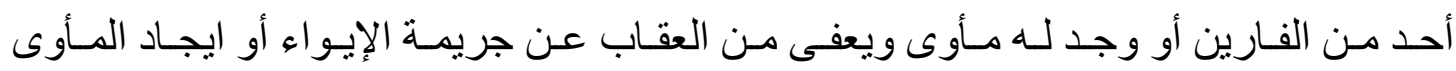

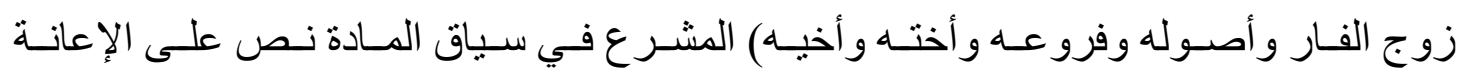

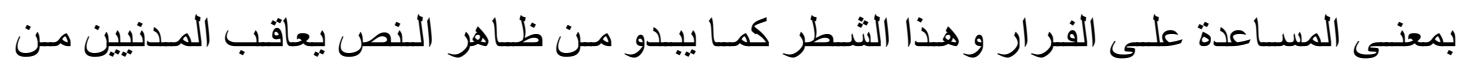

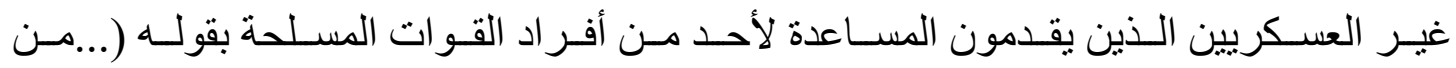

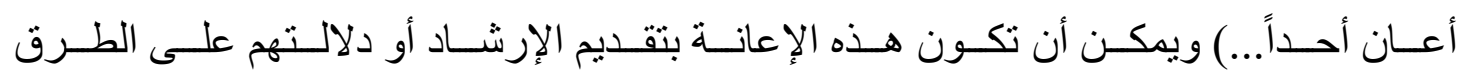

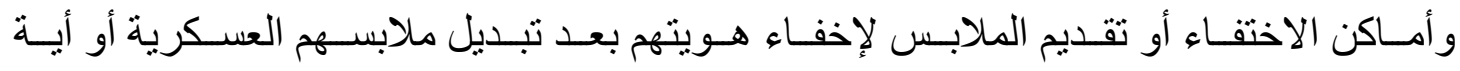

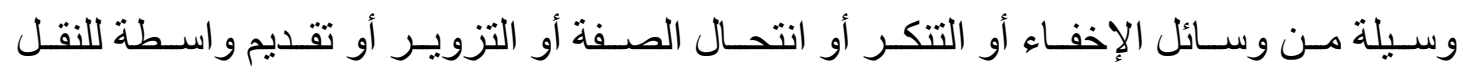

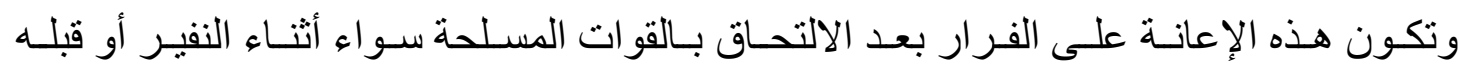

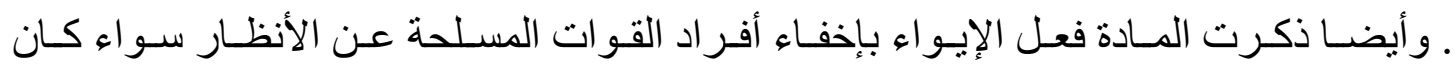

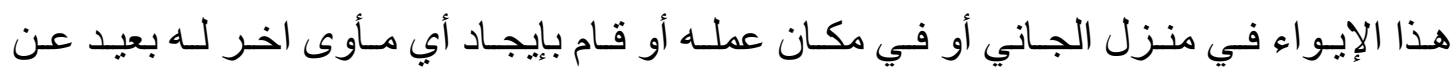

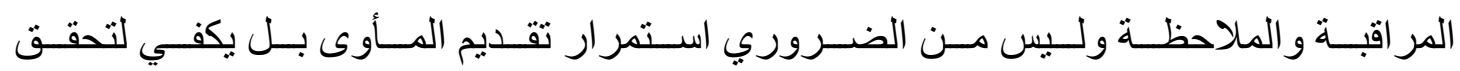

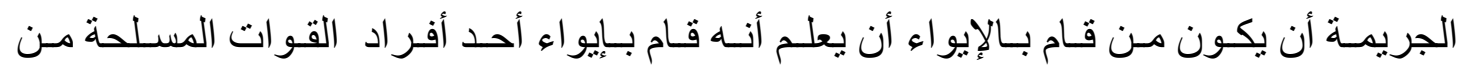


الفـارين و لا أهميـة لبو اعـث الإيـواء أو أيجـاد المـأوى ــوفي الثـطر ألأخيـر مـن نـص المـادة

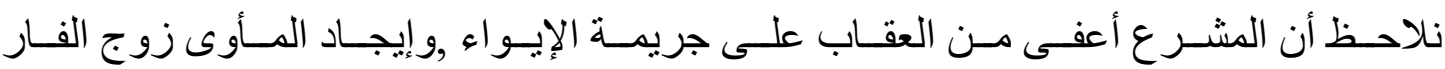

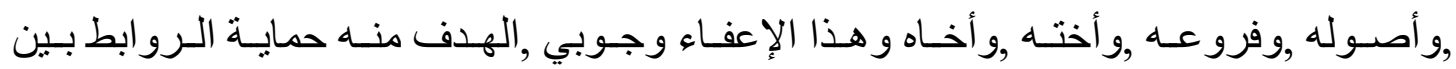
الأصول و الفروع و الأزواج و الأثشاء.

(The second requirement) المطلب الثاني

جريمة الهروب في التشريعات العسكرية المقارنة

\section{Fleeing crime in comparative legislations}

بعـد أن بينـا في موضـع النص على الهـروب في التشـريع العر اقي سـنبين في هـذا

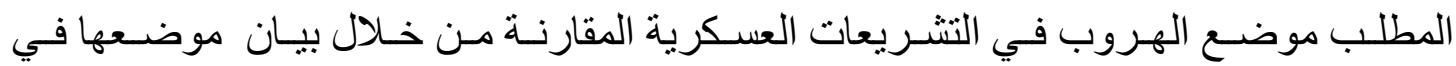
كل من التشريع ألأردني و البحريني و السعودي و اليمني و المصري

(section I) الفرع الأول

التشريع العكري ألأردني (Jordanian military legislation)

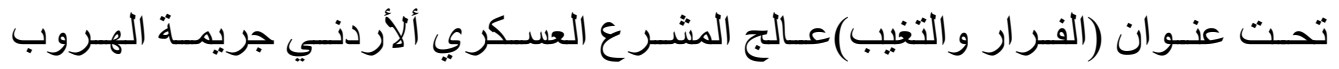

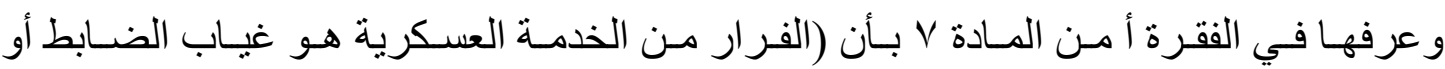

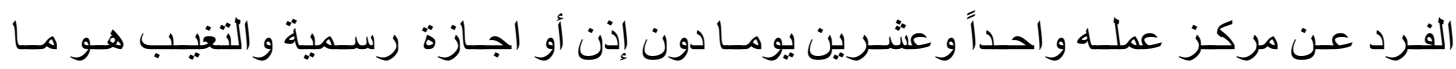

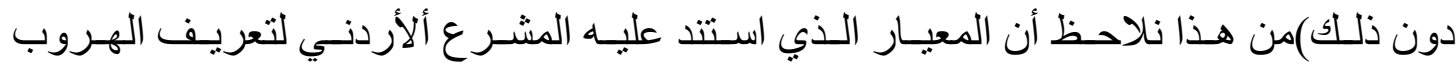

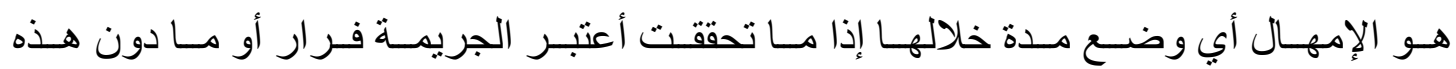

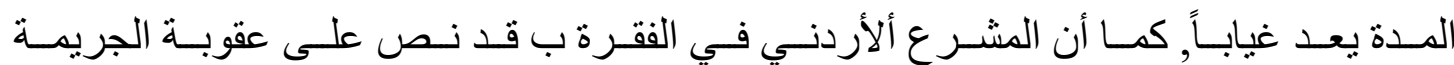

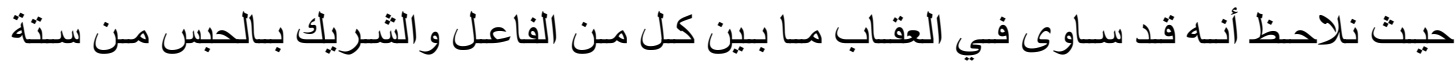

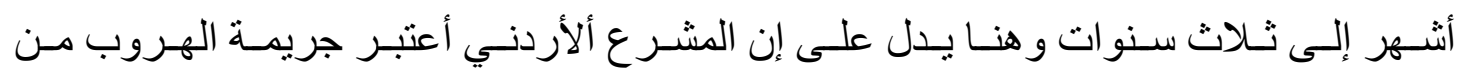

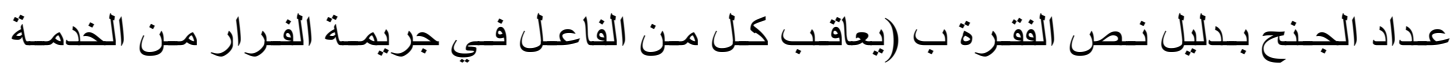

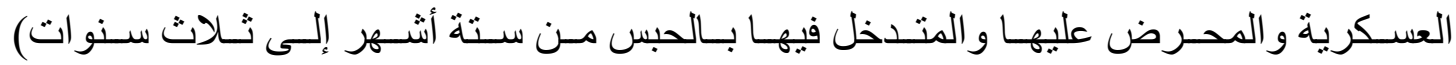

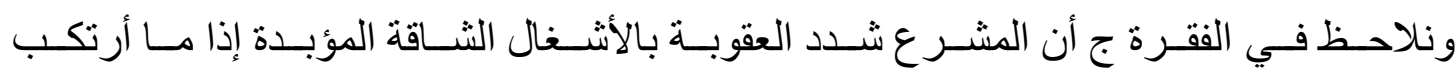


الجريمـة في زمـن الـرب , بمعنى أنـه جعل مـن الحرب ظرفـا مشـداً وهذا مـا نصـت عليهـ

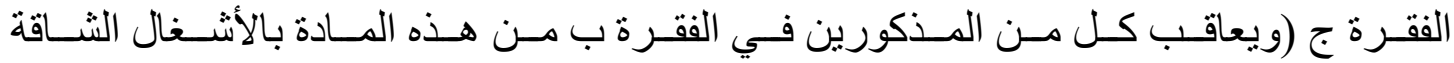
ألمؤبدة إذا ما وقع الفعل في زمن الحرب) (1).

(Section II ) (الفرع الثاني

التشريع العكري اليمني ( Yemeni military legislation)

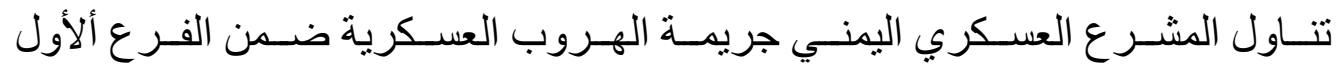

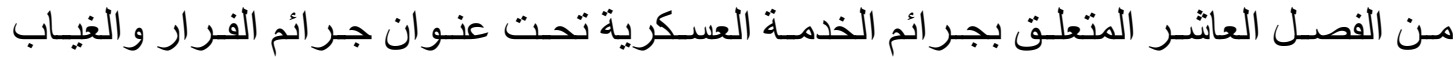

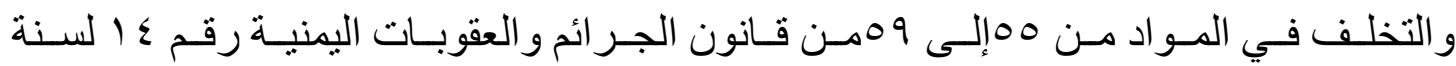

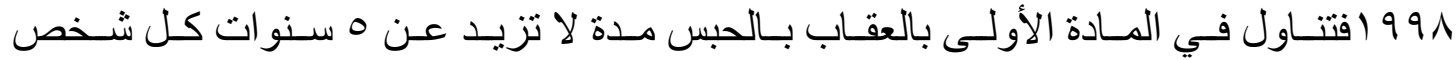

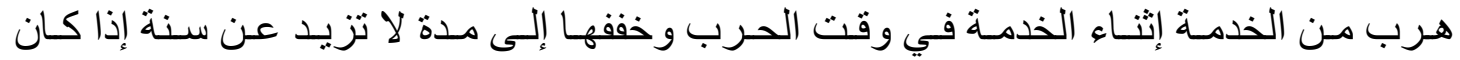

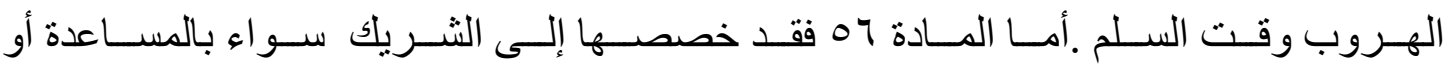

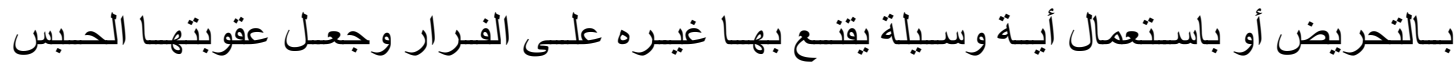

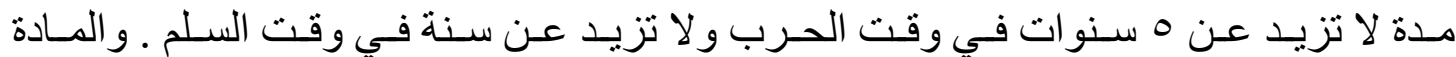

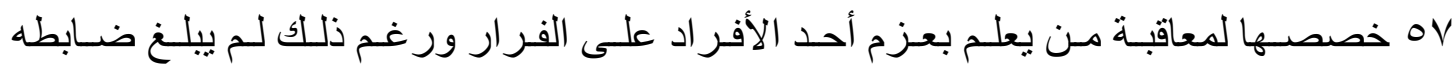

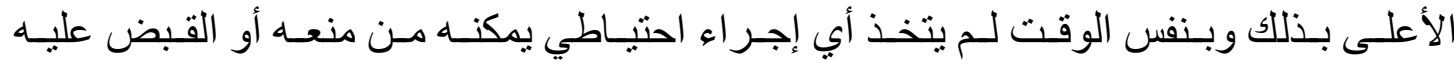

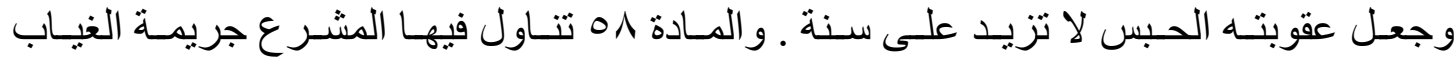

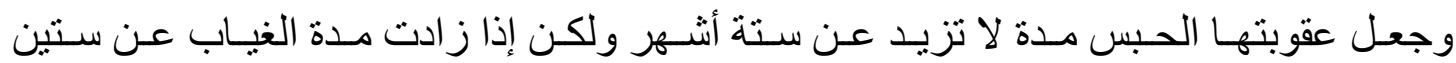

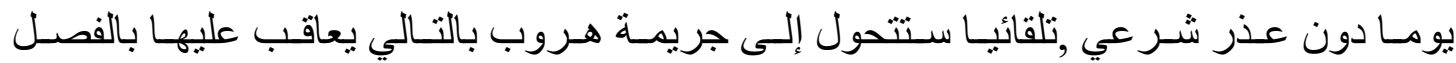
من هنا نلاحظ أن المشرع اليمني أخذ بالإمهال للتفرقة بين الهروب وبين الغياب(بـع).

\section{(Section III ) الفرع الثالث}

\section{التشريع العسكري المصري (Egyptian military legislation)}

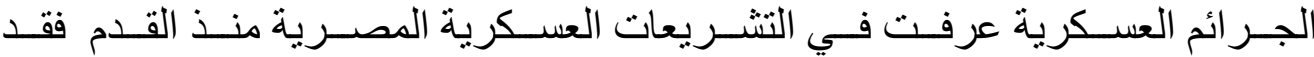

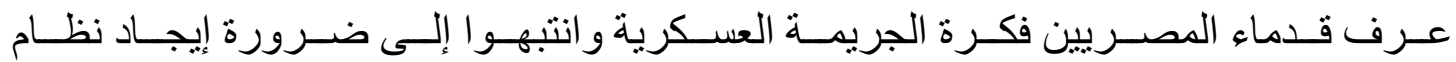




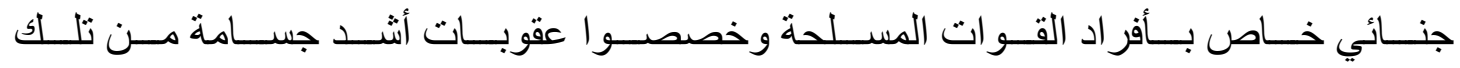

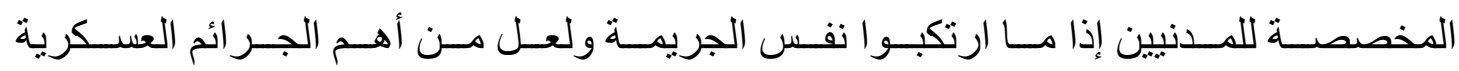

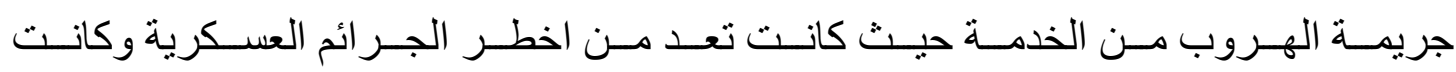

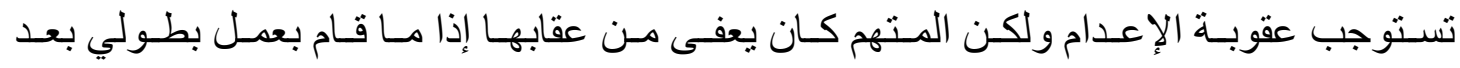
ذللك يعوض فيه جريمته في الهروب (T) ع ) .

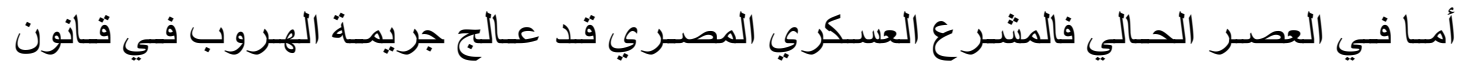

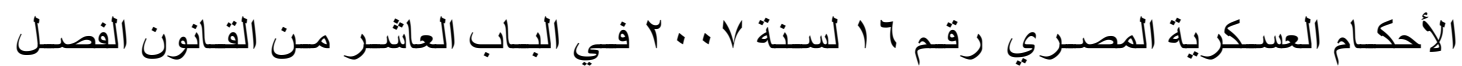

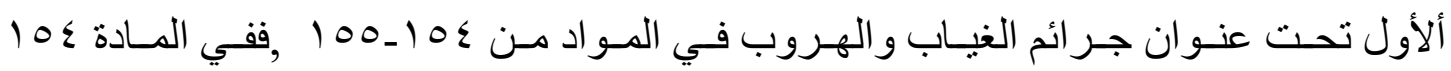

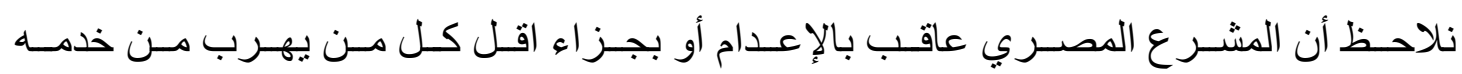

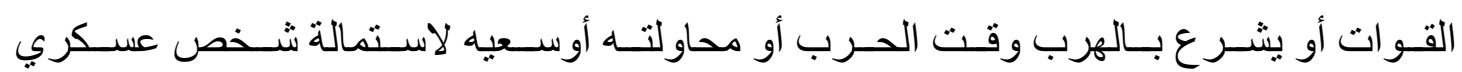

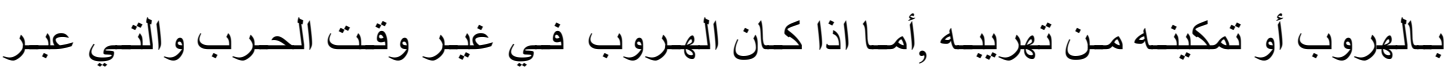
عنها المشر ع المصري بلفظ الميدان فتكون العقوبة الحبس أو بجزاء أقل منها.

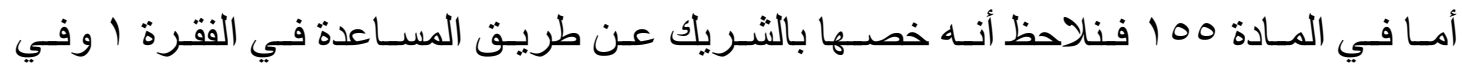
الفقرة ب تنـاول حالـة مـن بعلم بعزم احـ بـالهرب مـن القوات المسلحة ولم يخبر قائـده بـذلك

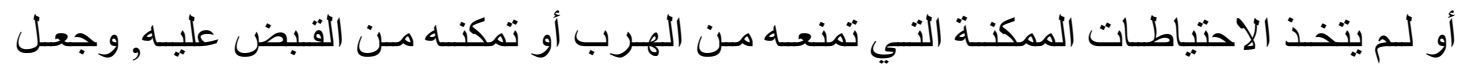
العقوبة هنا الحبس أو جزاء أقل منصوص عليه في هذا القانون 


\section{(conclusion) الخاتمة}

تـأتي أهميـة جـر ائم الهـروب مـن خطـورة هـذه الجـر ائم لمساسـها المباشـر بالمصـلحة

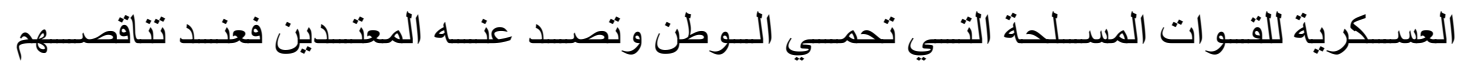

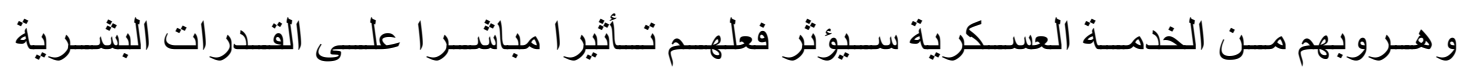
للقو ات المسـلحة وبـالأخص ان كانـت الدولـة في حالـة حـرب او ظـرف غيـر اعتيـادي على

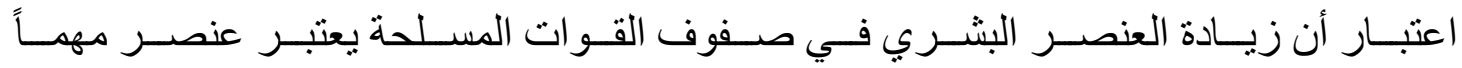

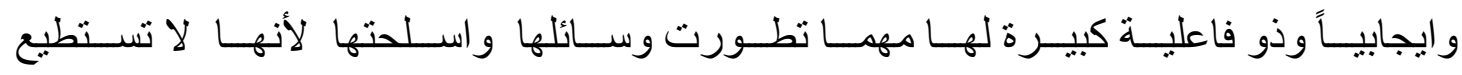

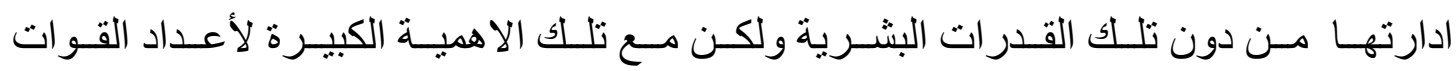

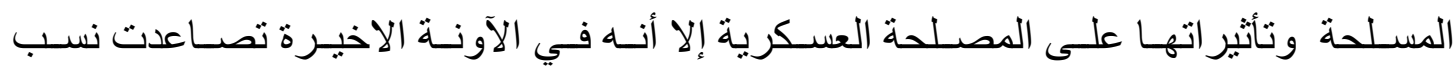

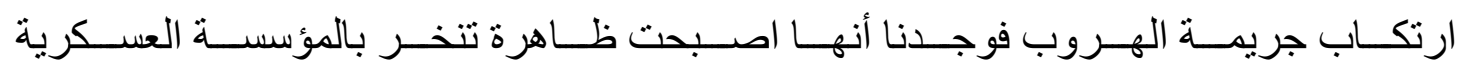
فأصـبحت الـز اد اليـومي للمحـاكم العسكرية إذ لا تكــاد تخلـو محكمـة عسكرية مـن النظـر في عدة قضايا هروب يوميا وتوصلنا من البحث في الهروب إلى ما يلي:

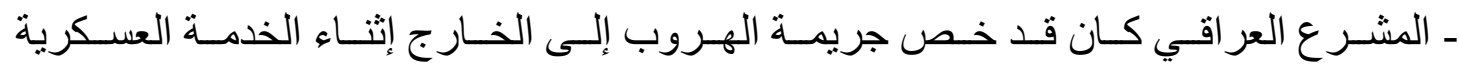
بتثـريع خـاص ألا وهـو قـانون معاقبـة الهـروب خـار ج الـبلاد إثتـاء الخدمـة العسـكرية رقـم

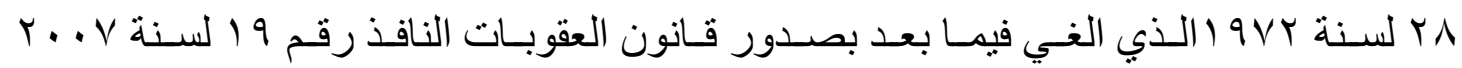

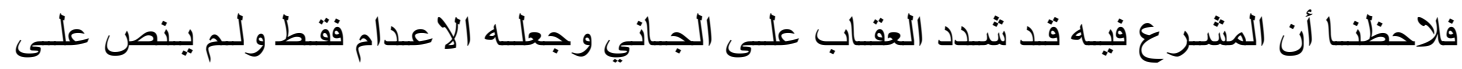

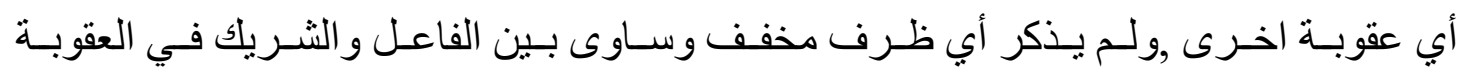

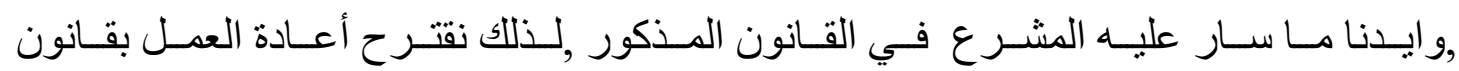

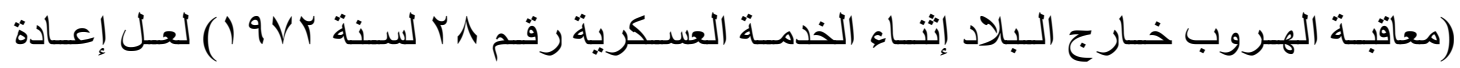
العمل به يكون سبباً في الحد من تز ايد تلك الجريمة

ـلتعـدد صـور جريمــة الهـروب العسـكرية كـان الأجـدر بالمشـرع ع أن يطلـق عليهـا تسـمية

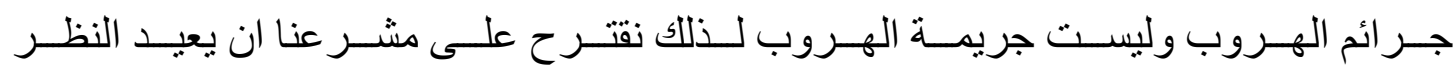
بالتسمية المذكورة .

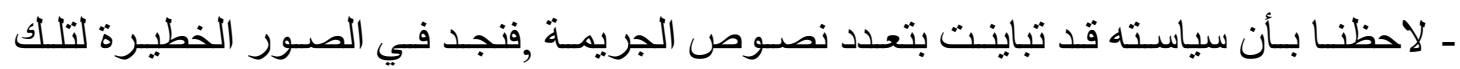
الجريمـة كجريمـة الهـروب إلـى جانـب العـدو اكتفى بـذكر عقوبـة الاعـدام دون ان يتـرك أي مجـال لسـلطة القاضـي في اخيـار عقوبـة اخـرى و لا شـكـ ان مشـر عنا العسـكري كـان موفقـا

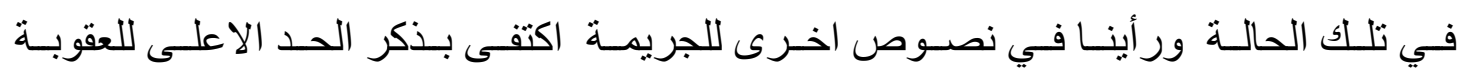




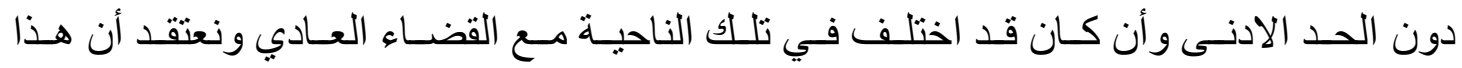

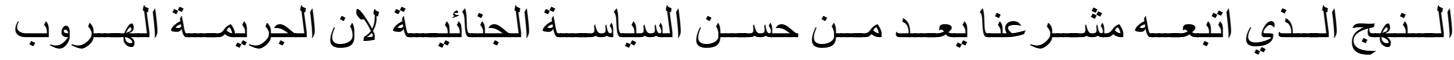

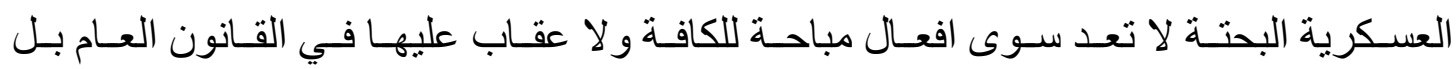
ربمـا قـد تكـون موضـع مخالفـة ادبيـة فقط إلا إنهـا تصـبح جريمـة خطـرة عندما ترتكب مـن شخص عسكري .

ـكــا لاحظنـا مـن نصــوص الجريمـة أن المشـرع تجنـب التفرقـة فـي العقوبـة بـين الضــابط وبقيـة العسـكريين وإذ لا بــد مـن أن تشـدد علـى الاول لأن الضــرر الـذي سـيلحق بالوحـدة

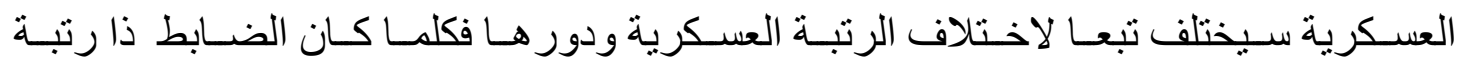
اعلى كلمـا كـان هروبـهـ ذا اثـر اكبـر وأخطـر لـذللك نقتـرح على مشـر عنا بضـرورة التفريـق في العقوبة بين الضـابط وغيره من العسكربين ـ كـــا أن مشـر عنا العسـكري العر اقـي لـم يعتبر هــا مـن الجـر ائم المخلــة بالثـرف و الامانـة مــع انتــانـرى أن الهـروب مــن الخدمـة العسـكرية جريمــة مخلـة بالثــرف و الامانــة لأن

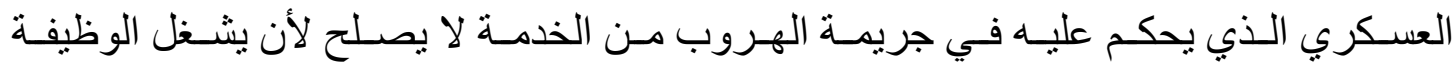

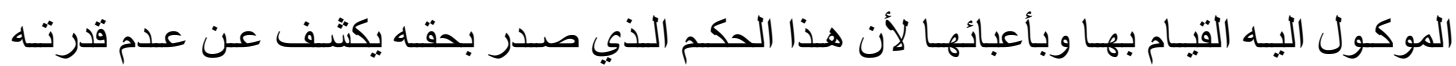

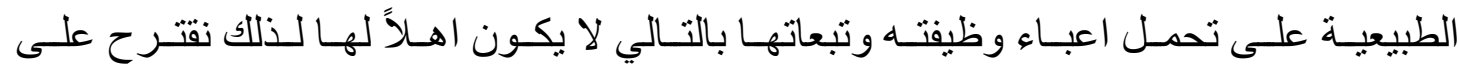
مشـر عنـا اعـادة النظـر فيمـا سـبق ويعتبر هـا جريمـة مخلــة بالثـرف و الامانـة فقيمـة الجـيش لا لا تكمـن بعدده فقط بـل بو لائـهـ وتجهيزه رفالتمسـك بالعناصـر غيـر الكفؤة في القـوات المسـلحة يــؤثر ســلباً فـي كفــاءة القــوات المسـلحة ويضــر بالمصــلحة العسـكرية اولاً واخيـراً .و لأن

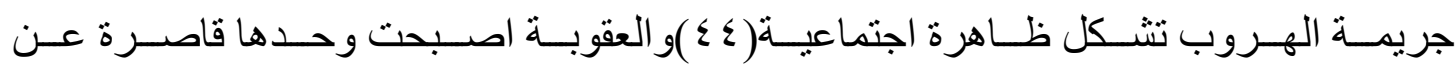
ردعهـا و الحـد منهـا لـذلك يتوجب علينـا أن نشـير الى عدد مـن المقترحسات التـي ربمـا تسـاهم في الحد منها :- (2 - n

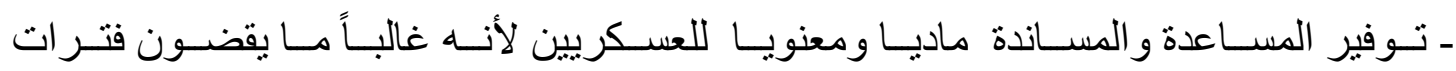

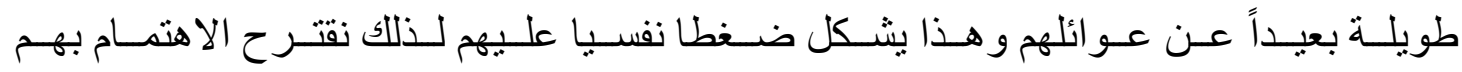

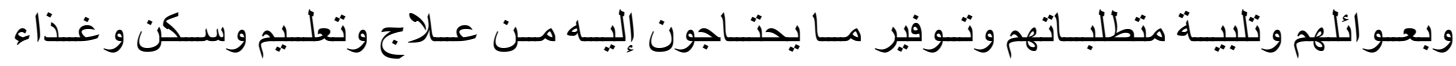
احياناً وكذلك منحهم اجاز ات دورية والتأكيد على ان ينالونها بأوقاتها المحددة. 
ـتنميـة روح المو اطنـة لـدى الافـر اد بشكل عـام و العسكريين بشكل خـاص عـن طريـق عقد

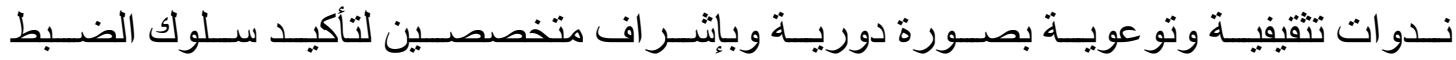
الذاتي المبني على الاقتناع لا على الاجبار و الالز ام

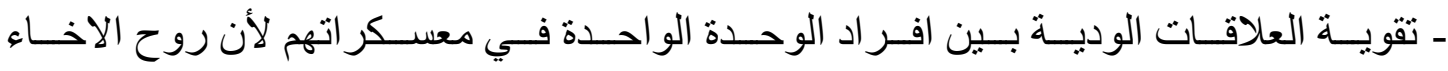

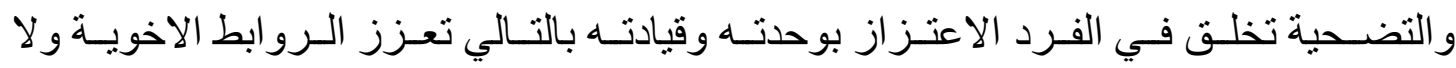
تجعله يفكر في الهرب وتاركاز زملائه خلفه.

-وجـوب اختيـار القـادة العسكريين مـن ذي الكفـاءة العاليـة لأن ذلـك سـيرفع الـروح المعنويــة

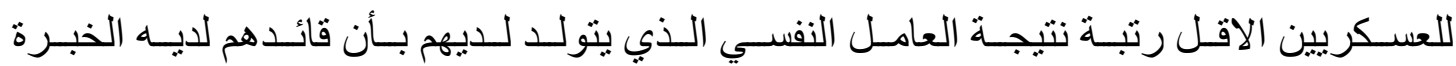
و الالمام و المعرفة و المحافظة على مرؤوسيه من الاخطار غير المحسوبة.

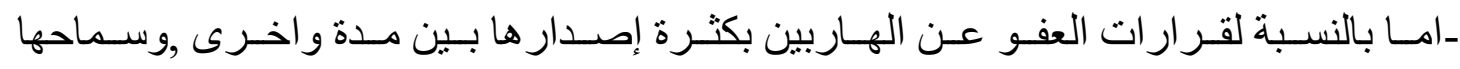

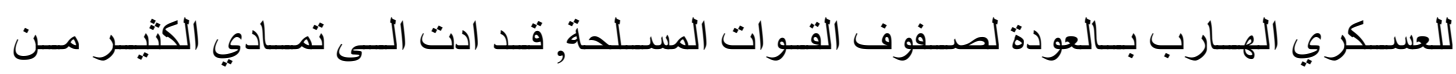

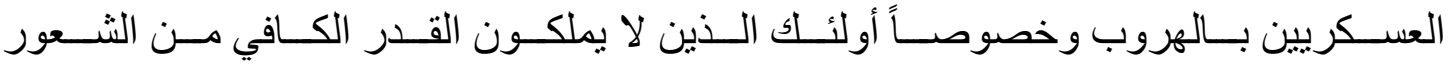

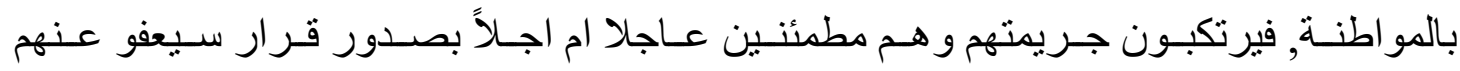

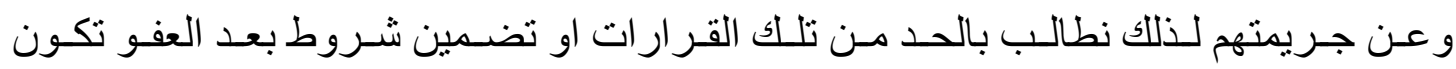

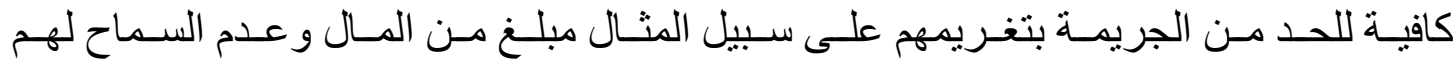
بالعودة لصفوف القوات المسلحة لأن ما يهمنا في العسكريين الو لاءو الوطنية لا العدد.

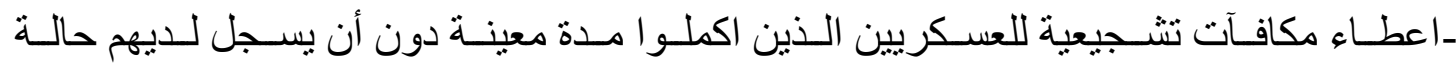

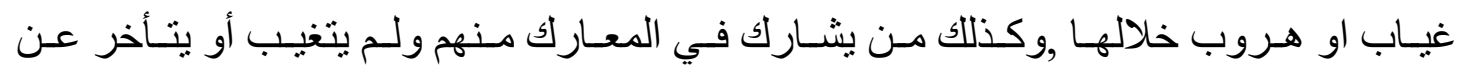
تأدية واجبه بتفاني و عزم . ت متروب

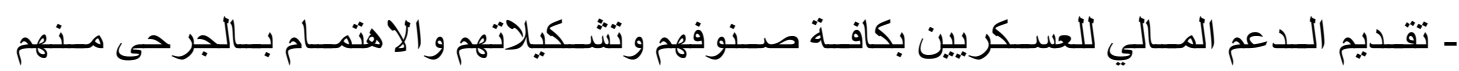

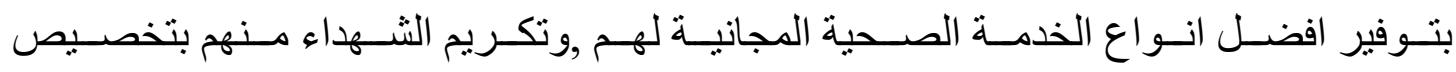
مخصصات مالية وار اضي سكنية لعو ائلهم .

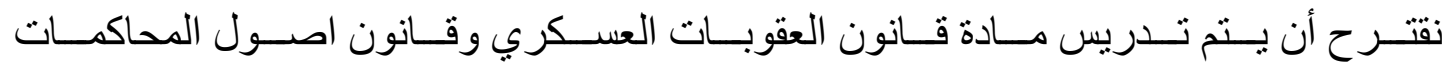
الجز ائية العسكري في كليات القانون لأنها اصبحت من المجاهيل و المنسيات 


\section{هوامش البحث}

\section{Margins}

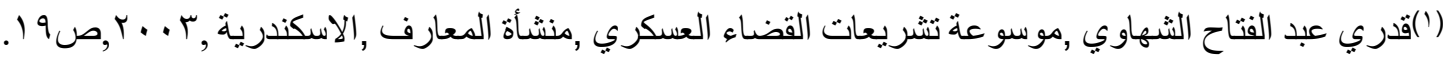
(ז)مصطفى فاضل كريم الخفاجي ,تاريخ القانون في المجتمعات القديمة(قانون حمور ابي )انموذجا رمجلة بابل

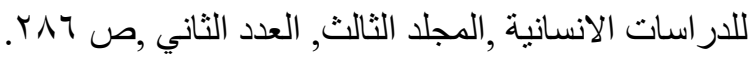
(r) سعد ابر اهيم الاعظمي ,موسو عة الجر ائم الماسة بأمن الدولة الخارجي ,بغداد (๕) صدقي عبد الرحيم ,موسو عة صدقي في القانون الجنائي (مشرو عية القانون و القضاء العسكري ) ),المجلد الثالث

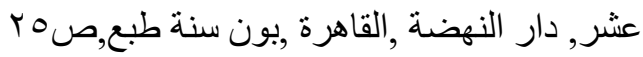

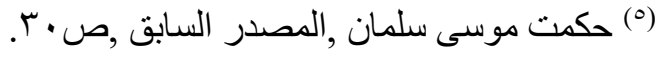
(?) فهر محمد النفيسة ,اجر اءات التحقيق و المحاكمة في الجر ائم العسكرية, رسالة ماجستير رجامعة نايف العربية للعلوم الامنية ,الرياض ,بلا سنة طبع ,ص r.

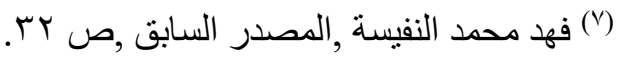
(^) بغاته عبد السلام ,مقياس القانون الجنائي العام رحاضر ات لطلبة كلية اصول الدين والشريعة ,جامعة الامير

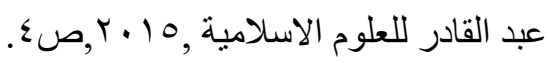

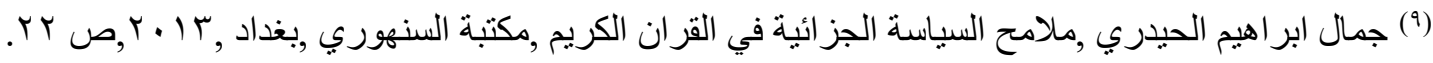

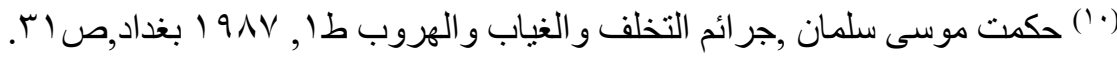
(' (') جبر ان مسعود ,قاموس الر ائد ,بيروت ,دار العلم للملايين,ص • 107.

(r'أبن منظور ,أبي الفضل جمال الدين محمد بن مكرم ,كتاب لسان العرب ,المجلد ألأول,دار صادر بيروت VArص, 199.,1 b, (T) ابر اهيم مصطفى ,أحدد حسن الزيات ,حامد عبد القادر ,محمد علي النجار, المعجم الوسيط ,الجزء الثاني,

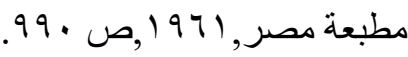

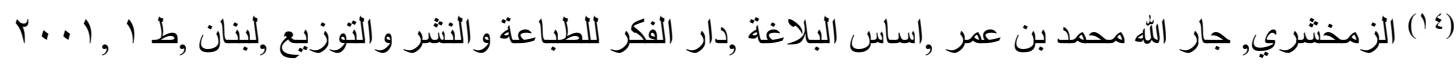




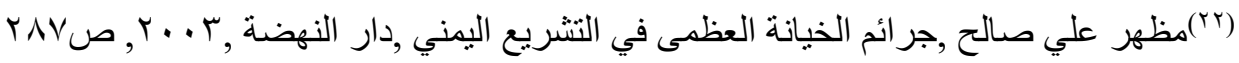

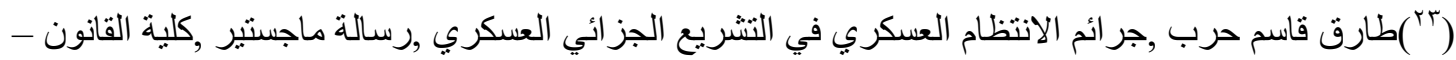

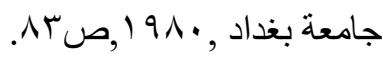

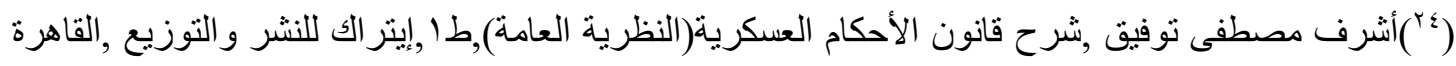
rर० (ro)

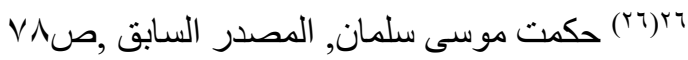

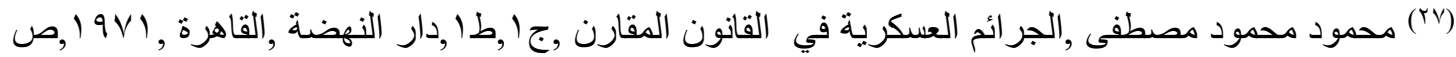

و لا يفوتنا أن نذكر بأن لمشر ع العسكري العر اقي عرف سابقا في القانون الملغي جريمة التخلف و التي تعني الهرب قبل الالتحاق أما في القانون النافذ لم نجد أب نص للتخلف كون أن الخدمة في الجيش العر اقي حاليا اختبارية وليست إلز امية كما كانت في القانون السابق

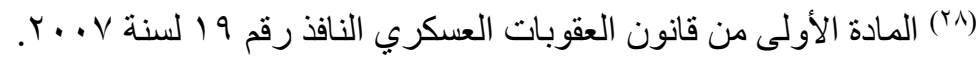

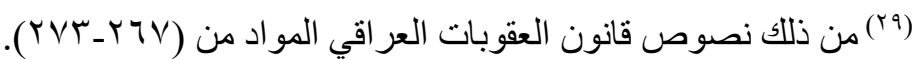

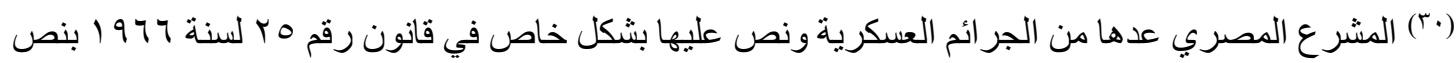

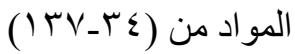

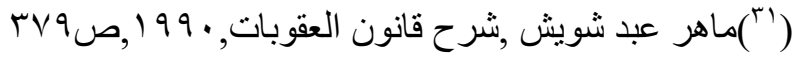

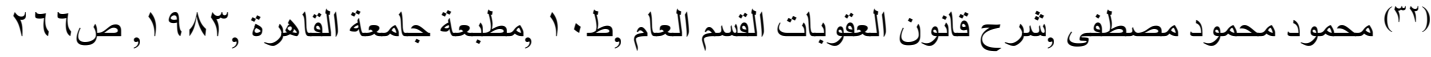
("rr) عزت مصطفى الدسوقي ,موسوعة شرح قانون الاحكام العسكرية ,الكتاب الأول ,دار محمود للنشر و التوزيع $.00 ص, 199 \mathrm{~V}$, (צ׳برمد عدنان عبود, جرائم هرب المحكومين والمقبوض عليهم والمساعدة عليه ,رسالة ماجستير ,جامعة

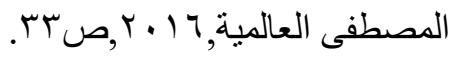

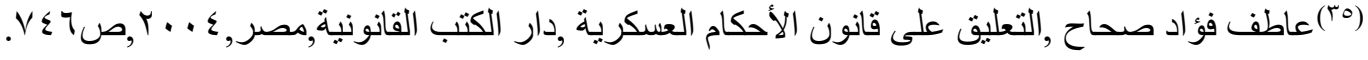
(דr)علي حسين الخلف, سلطان عبد القادر الثناوي ,ا لمبادئ العامة في قانون العقوبات ,المكتبة القانونيةـ

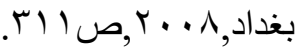

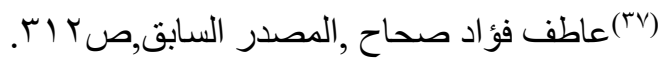
(^)مصطفى فاضل كريم, تاريخ القانون في المجتمعات القديمة(قانون حمور ابي انموذجاً),بحث منشور في مجلة

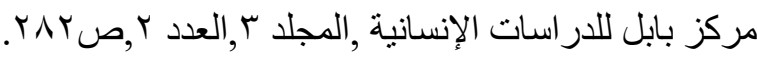
(19)علي جاسم عباس و طارق قاسم حرب ,شرح الاحكام القانونية الخاصة بالغياب و الهروب ,ط r, بلسلة الثقافة

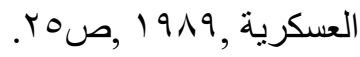
(•) العدو يشمل الدولة التي تكون في حالة حرب مع العر اق ور عايا تللك الدولة أو العصاة المسلحين 


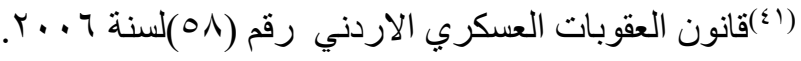

(ז\&)صدقي عبد الرحيم ,موسوعة صدقي في القانون الجنائي, المجلد الثالث عشر مشروعية القانون والقضاء

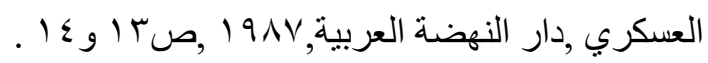

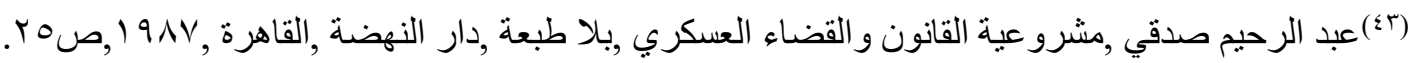
(؛ و الظاهرة الاجتماعية عبارة عن سلوك أو فعل عام صـادر عن مجمو عة من الناس ,وينظم هذا السلوك حياتهم ويحكم تصرفاتهم وتتشكل دو افع نلك الظاهرة لدى الافراد وقد تكون تلك الدوافع سلبية بالتالي ستتولد ظاهرة اجتماعية سلبية أو مشكلة أو قد تكون دو افع طبيعية تثكل ظو اهر طبيعية او مقبولة ,وقد تكون في بعض الاحيان سلوكيات فرد معين بداية لتكون ظاهرة اجتماعية فالأفر اد يتأثرون ببعضهم البعض بحكم وجودهم بنفس البقعة الجغر افية أو تو اصلهم بشكل متكرر للمزيد انظر خصائص الظاهرة الاجتماعية مقال مكتوب بواسطة فاطمة مشعلة على الموقع 


\section{المصادر}

\section{Reference}

اولاً: القرآن الكريم

ثانياً: الكتب والرسائل (Books and thesis) أبر اهيم مصطفى, أحمد حسن الزيات, حامد عبد القادر, محمد علي النجار, المعجم الوسيط, الجزء الثاني, -I مطبعة مصر. ـ أبن منظور, أبي الفضل جمال الدين محمد بن مكرم, كتاب لسان العرب, الدجلد ألأول, دار صادر بيروت, $.1,199 \cdot b$ ـ أشرف مصطفى توفيق, شرح قانون الأحكام العسكرية (النظرية العامة), طا, إيتر الك للنشر و التوزيع, القاهرة, III r...

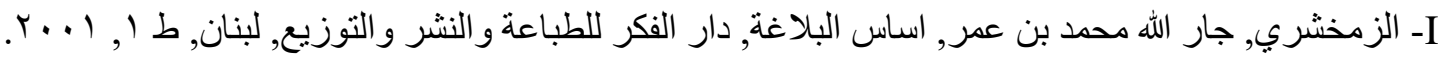
- V Vغاته عبد السلام, مقياس القانون الجنائي العام, محاضر ات لطلبة كلية اصول الدين و الثريعة, جامعة الامير عبد القادر للعلوم الاسلامية, 10 • ب. - جبران مسعود, قاموس الر ائد, بيروت, دار العلم للملايين. VI

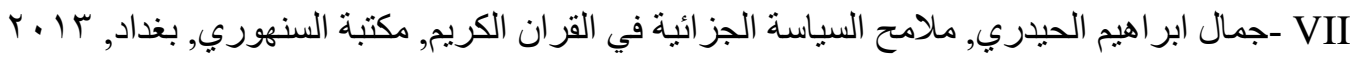

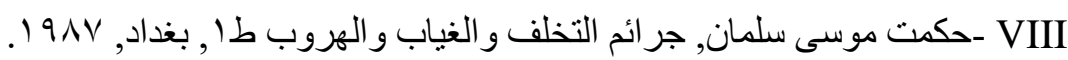
- سرمد عدنان عبود, جر ائم هرب المحكومين والمقبوض عليهم والمساعدة عليه, رسالة ماجستير, جامعة

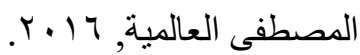
سعد ابر اهيم الاعظمي, موسوعة الجر ائم الماسة بأمن الدولة الخارجي, بغداد, 999 X صدقي عبد الرحيم, موسوعة صدقي في القانون الجنائي (مشروعية القانون و القضاء العسكري), المجلد

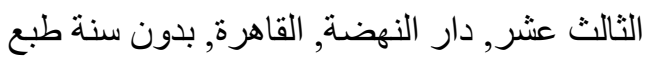

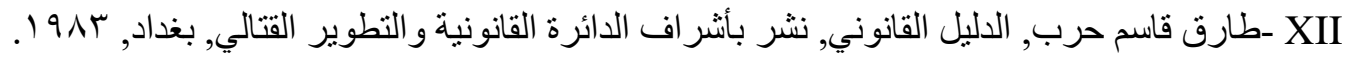
- طارق قاسم حرب, جر ائم الانتظام العسكري في التشريع الجزائي العسكري, رسالة ماجستير, كلية القانون

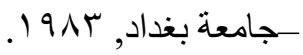

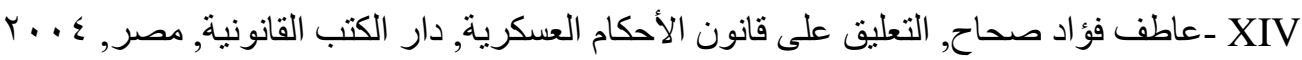
- عزت مصطفى الدسوقي, موسوعة شرح قانون الاحكام العسكرية, الكتاب الأول, دار محمود للنشر و التوزيع, 1999. - علي حسين الخلف, سلطان عبد القادر الثاوي, ا لمبادئ العامة في قانون العقوبات, المكتبة القانونيةـ بغدادم. . ب. - علي جاسم عباس و طارق قاسم حرب, شرح الاحكام القانونية الخاصة بالغياب و الهروب, طץ, سلسلة 
- فهد محمد النفيسة, اجر اءات التحقيق و المحاكمة في الجر ائم العسكرية, رسالة ماجستير, جامعة نايف العربية للعلوم الامنية, الرياض, بلا سنة طبع ـقدري عبد الفتاح الثهاوي, موسو عة تشريعات القضاء العسكري, منشأة المعارف, الاسكندرية.

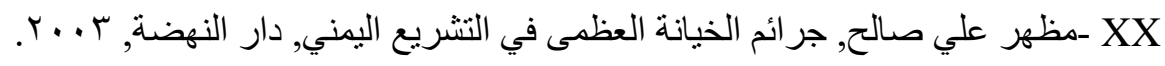

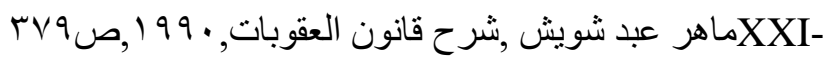
محمود محمود مصطفى, الجرائم العسكرية في القانون المقارن, جXXII ص محمود محمود مصطفى, شرح قانون العقوبات القسم العام, ط• 1, مطبعة جامعة القاهرة, rAXIII ثالثاً: البحوث (Research) Iصطفى فاضل كريم, تاريخ القانون في المجتمعات القديمة (قانون حمور ابي انموذجاً), بحث منشور في مجلة

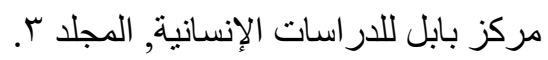

